\title{
STRUCTURE AND X-RAY CONFORMATION OF PSEUDODESMINS A AND B, TWO NEW CYCLIC LIPODEPSIPEPTIDES FROM PSEUDOMONAS BACTERIA
}

Davy Sinnaeve ${ }^{\mathrm{a}, *}$, Catherine Michaux ${ }^{\mathrm{b}}$, Johan Van hemel ${ }^{\mathrm{c}}$, Jan Vandenkerckhove ${ }^{\mathrm{c}}$, Eric Peys ${ }^{\mathrm{c}}$, Frans A.M. Borremans ${ }^{a}$, Benedikt Sas ${ }^{c, \uparrow}$, Johan Wouters $^{b}$ and José C. Martins ${ }^{\mathrm{a}, *}$

${ }^{a}$ NMR and Structure Analysis Unit, Department of Organic Chemistry, Ghent University, Krijgslaan 281 S4 B-9000 Gent, Belgium

${ }^{\mathbf{b}}$ Laboratoire de Chimie Biologique Structurale, Université de Namur, rue de Bruxelles 61, B-5000 Namur, Belgium

${ }^{\mathrm{c}}$ Kemin Pharma, Atealaan 4H, B-2200 Herentals, Belgium

${ }^{\dagger}$ Current address: Department of Food Safety and Food Quality, Ghent University, Coupure Links 653, blok B, 9000 Gent, Belgium

*Corresponding authors. Tel. +32 (0)9 264 4469; fax: +32 (0)9 2644972

E-mail adresses: Davy.Sinnaeve@UGent.be (D. Sinnaeve), Jose.Martins@UGent.be (J. C. Martins)

Tetrahedron, Volume 65, Issue 21, 2009, 4173-4181

doi:10.1016/j.tet.2009.03.045

www.elsevier.com/locate/tet
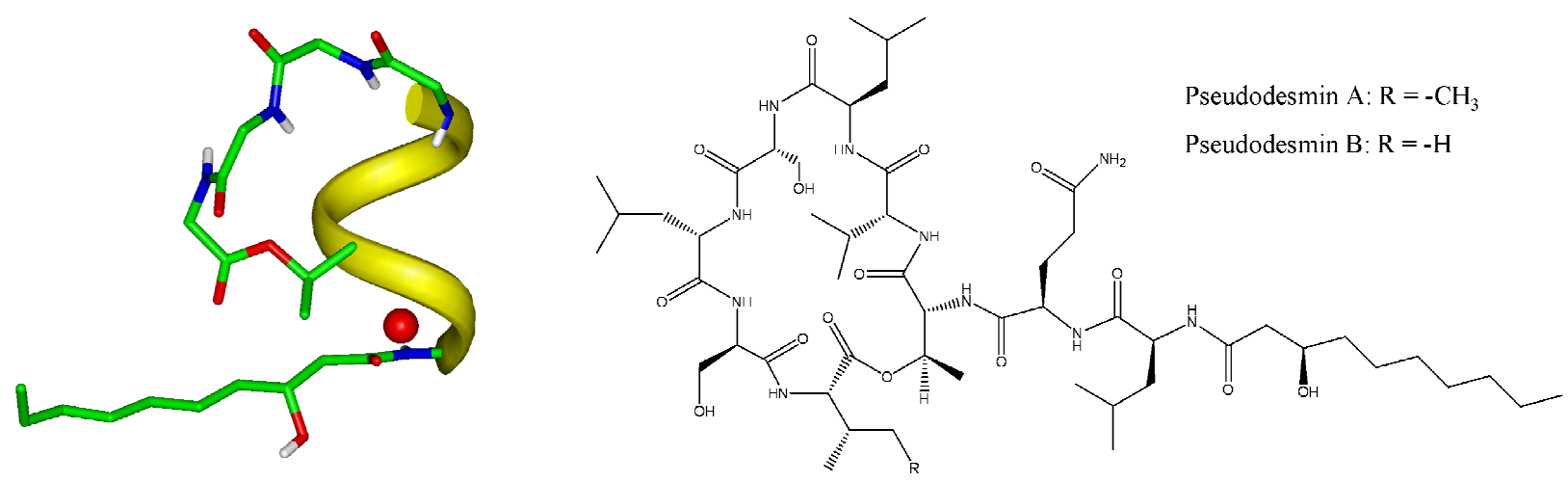


\begin{abstract}
Two new cyclic lipodepsipeptides named pseudodesmin A and $B$ have been isolated from Pseudomonas bacteria collected from the mucus layer in the skin of the black belly salamander. Both compounds show moderate antibacterial activity against Gram positive bacteria, including MRSA. Complete ${ }^{1} \mathrm{H},{ }^{13} \mathrm{C}$ and ${ }^{15} \mathrm{~N}$ NMR assignment of both compounds afforded their covalent structure and served to guide the analysis of LC-MS and X-ray diffraction data from which the final stereochemistry could be established. Both molecules can be categorized as new members of the viscosin group of cyclic lipodepsipeptides.
\end{abstract}

\title{
KEYWORDS
}

lipodepsipeptide, viscosin group, pseudodesmin, Pseudomonas, Plethodontidae, X-ray structure, NMR

\section{Introduction}

Cyclic lipodepsipeptides (CLPs) are secondary metabolites produced mainly by Pseudomonas bacteria $^{1,2}$, and are of interest as they display potential anti-microbial activity. They consist of an oligopeptide chain that forms a cyclic structure via a lactone (or so-called depsi) bond involving the Cterminus, and a long fatty acid chain that is connected to the exocyclic N-terminus. CLPs are believed to have several extracellular functions, including surface motility, biosurfactant activity and antimicrobial activity. Because CLPs are not bound to the rules of ribosomal synthesis ${ }^{2}$, uncommon or modified amino acids, including D-amino acids, are often present. They have been classified into several groups, including the viscosin group, the amphisin group, the syringomycin group and the tolaasin group ${ }^{1,2}$. With the exception of the latter, the peptide chain length within each group is the same and a similar sequence distribution pattern in hydrophobic and hydrophilic residues can be observed. The viscosin group comprises viscosin ${ }^{3}$, viscosinamide, White Line Inducing Principle (WLIP) $)^{5}$, massetolide $\mathrm{A}-\mathrm{H}^{6}$ and pseudophomin $\mathrm{A}$ and $\mathrm{B}^{7}$, which all consist of 9 amino acid residues, 7 of which form the cyclic structure via lactone bond formation between the C-terminus and the side chain of a D-allo-Thr at position 3. They are produced by several Pseudomonas species, including $P$. viscosa ${ }^{8}$, P. libanensis ${ }^{9}$ (viscosin), different strains of $P$. fluorescens (viscosin ${ }^{10}$, viscosinamide ${ }^{4}$, the massetolides ${ }^{11}$ and pseudophomins ${ }^{7}$ ) and P. reactans $\left(\right.$ WLIP $\left.^{5}\right)$.

Here we report the isolation, biological activity and conformation of two new CLPs, pseudodesmin A and B (Figure 1). They originate from Pseudomonas bacteria living in the mucus layer of salamanders of the Plethodontidae family and are shown to display moderate antibiotic activities. Full elucidation of the covalent structure was achieved through NMR, LC-MS and X-Ray diffraction analysis, revealing pseudodesmin $\mathrm{A}$ and $\mathrm{B}$ to be new members of the viscosin group. For certain viscosin group members, transmembrane pore formation has been proposed as the most likely biological mode of action ${ }^{12,13}$. Using the crystal structure of pseudodesmin A, potential links between the structure and this mode of action are discussed.

\section{Results}

\subsection{Pseudodesmin A and B display moderate antibacterial and antiviral activity}

The newly isolated compounds were scrutinized for biological activity against a series of Tier one pathogens. The results of the antibiotic, antimycotic, antiviral and cytotoxic screenings are presented in Tables 1 and 2. Pseudodesmin A and B both possess bacteriostatic properties against Gram positive bacteria, including several resistant strains. However, no bacteriocidal effects were observed at concentrations up to $25 \mu \mathrm{g} / \mathrm{ml}$ (maximum test dosage). Only a modest antiviral activity against HIV1 and VZV and some cytostatic activity can be observed for the mixture of pseudodesmin A and B, whereas no significant antimycotic activity is observed. 


\subsection{Structure elucidation of pseudodesmin A and B}

Initial LC-MS studies revealed the molecular weights of pseudodesmin A and B to be 1124.2 Da and 1110.2 Da respectively. Using MS/MS analysis data alone, no conclusive proposal for the molecular structure could be made, however the presence of a cyclic oligopeptide fragment was already suspected. In addition, the absence of a free amino group was revealed from a negative response to a ninhydrine colouring test. The oligopeptide nature was confirmed using NMR spectroscopy. The 2D TOCSY spectrum showed correlations between amide resonances and aliphatic spin systems characteristic for amino acid moieties. Full assignment and structure confirmation was achieved in a $2 \mathrm{mM}$ acetonitrile solution. Combined analysis of a $2 \mathrm{D}$ DQF-COSY and a ${ }^{1} \mathrm{H}-{ }^{13} \mathrm{C}-\mathrm{HSQC}$ spectrum revealed 10 separate spin systems for pseudodesmin A, corresponding to 9 amino acid residues $(1 \mathrm{Glx}$, 3 Leu's, 1 Thr, 2 Ser's, 1 Val and 1 Ile) and a 2-hydroxynonyl (R) spin system. The sequence of these residues was established through a $200 \mathrm{~ms}$ NOESY spectrum from sequential $\mathrm{H}^{\alpha}$ to $\mathrm{H}^{\mathrm{N}}$ nOe's, including a connection between the $\mathrm{\alpha CH}_{2}$ of the 2-hydroxynonyl moiety and the $\mathrm{H}^{\mathrm{N}}$ of Leu1. In addition, nOe contacts between the $\gamma$ protons of the Glx spinsystem to two resonances in the amide region of the spectrum that exclusively correlate with each other in COSY and TOCSY spectra, established the Glx residue as a Gln. The primary structure of pseudodesmin A was thus established as R-Leu-Gln-Thr-Val-Leu-Ser-Leu-Ser-Ile. Finally, the ${ }^{1} \mathrm{H}-{ }^{13} \mathrm{C}-\mathrm{gHMBC}$ allowed to assign all the carbonyl ${ }^{13} \mathrm{C}$ resonances through ${ }^{2} \mathrm{~J}_{\mathrm{C}^{\prime} \mathrm{H}}$ coupling correlations with the $\mathrm{H}^{\mathrm{N}}$ or $\mathrm{H}^{\alpha}$ resonances. The 2hydroxynonyl spin system could be assigned to a 3-hydroxydecanoic acid (HDA) moiety. Most importantly, a clear ${ }^{3} \mathrm{~J}_{\mathrm{CH}}$ correlation between the $\mathrm{Thr} 3 \mathrm{H}^{\beta}$ and the Ile9 carbonyl resonances unambiguously demonstrated the presence of a lactone bond, revealing a cyclic heptapeptide structure with two exocyclic residues at the $\mathrm{N}$-terminus. The final covalent structure thus derived (Figure 1) was in agreement with the molecular weight previously determined by LC-MS. Finally, ${ }^{15} \mathrm{~N}$ assignments were established at natural abundance via a $2 \mathrm{D}^{1} \mathrm{H}^{-15} \mathrm{~N}$ gHSQC at $700 \mathrm{MHz}$. Structure elucidation and NMR assignment of pseudodesmin B were obtained in a similar fashion and revealed the substitution of the Ile 9 residue for a second Val residue as the only difference with pseudodesmin A, in accordance with the $14 \mathrm{Da}$ mass difference. The complete assignments of both molecules are collected in Tables 3 and 4, while $1 \mathrm{D}{ }^{1} \mathrm{H}$ and 2D HSQC spectra are provided in the supplementary data.

To establish the stereochemistry, pseudodesmin A was subjected to total hydrolysis followed by derivatization of the free amino acids with Marfey's reagent ${ }^{14}$ and LC-MS analysis. The presence of two L-Leu, one D-Leu, two D-Ser, one D-allo-Thr, one D-Val and one L-Ile could be established. After lengthy crystallization trials, a crystal structure of pseudodesmin A was obtained from acetonitrile solution, which finally revealed the absolute configuration of the remaining stereocentres ((3R)-HDA, D-Gln2 and the D-Leu at position 5), the LC-MS being critical to distinguish between both possible enantiomers of the crystal structure. Due to limited material, pseudodesmin B was not subjected to total hydrolysis for chromatographic analysis and crystallization trials remained unsuccessful. However, except for the Ile/Val substitution, no significant differences in chemical shifts and ${ }^{3} \mathrm{~J}_{\mathrm{HNH} \alpha}$ scalar couplings between pseudodesmin A and B can be observed. Therefore, we are confident that the stereochemistry is identical, since one or multiple inversions of a single stereocentre would undoubtedly have a strong impact on the overall conformation and thus on the aforementioned conformation sensitive NMR parameters.

Both products were subjected to high resolution mass spectrometry analysis, of which the experimental details and full results are described in the supplementary data. This was performed at the Research Institute of Chromatography in Kortrijk, Belgium. The analysis provided a molecular weight of the protonated ion $[\mathrm{M}+\mathrm{H}]^{+\cdot}$ of $1125.71396 \mathrm{Da}$ for pseudodesmin A and 1111.70019 Da for pseudodesmin $\mathrm{B}$, which is in good agreement with the respective molecular formulas of $\mathrm{C}_{54} \mathrm{H}_{96} \mathrm{~N}_{10} \mathrm{O}_{15}$ and $\mathrm{C}_{53} \mathrm{H}_{94} \mathrm{~N}_{10} \mathrm{O}_{15}$.

\subsection{The crystal structure of pseudodesmin A}

The crystal structure of pseudodesmin A is presented in Figure 2, while general crystallographic parameters are provided in Table 5. Crystallographic data (excluding structure factors) have been deposited with the Cambridge Crystallographic Data Centre as supplementary publication CCDC 685601. Copies of the data can be obtained, free of charge, on application to CCDC, 12 Union Road, 
Cambridge CB2 1EZ, UK, (fax: +44-(0)1223-336033 or e-mail: deposit@ccdc.cam.ac.uk). Based on the $\varphi / \psi$ angles collected in Table 6 , the conformation mainly consists of a short left-handed $\alpha$-helix ranging from D-Gln2 to D-Leu5. The helix is stabilized by two $\mathrm{i}+4 \rightarrow \mathrm{i}$ hydrogen bonds (Leu5 $\mathrm{NH} \rightarrow$ Leu1 CO and Ser6 NH $\rightarrow$ Gln2 CO) (Table 7) and is preceded by a type II $\beta$ turn over the L-Leu1-DGln2 dipeptide and followed by a type I' $\beta$-turn over D-Leu5-D-Ser6. Both are accompanied by the characteristic hydrogen bonds, involving the $\mathrm{NH}$ of Thr3 with the $\mathrm{CO}$ of the HDA moiety and the NH of Leu7 and the CO of Val4 respectively. The switch to the L-configuration at Leu7 ends the $\alpha_{\mathrm{L}}$-helix, the main chain veering away right-handedly. The alternating L-D-L configuration in the Leu7-Ile9 tripeptide allows the backbone to loop back and brings the carboxylic end of the main chain in an adequate position to form the lactone bond with the Thr3 side chain (Figure 3). The loop thus locks the $\mathrm{N}$ - and C-terminal ends of the $\alpha_{\mathrm{L}}$-helix together. It also caps the Thr3 and Val4 CO's by forming additional hydrogen bonds with the Ser8 NH and Leu7 NH respectively. The Ile9 NH is not involved in any intramolecular hydrogen bond. All intramolecular and further intermolecular hydrogen bonds are listed in Table 7. Some of the intermolecular hydrogen bonds involve a single water molecule that acts as a hydrogen bond mediator between the C-terminal end of one molecule, where it caps the free carbonyl groups of Ser6 and Leu7, and the N-terminal end of the next one, where it interacts with the amide of Leu1.

The organization of the individual molecules is such that the hydrophobic side chains are packed together, delimiting large empty spaces between different units. The long alkyl chain of the HDA extends out into these spaces, where the high B-factors at the end of this chain are indicative of a higher degree of motional freedom.

\section{Discussion}

\subsection{Biological activity of the pseudodesmins and comparison with the viscosin group}

The current need for new lead compounds and antibiotic agents that circumvent the increasing levels of resistance against antibacterial and antiviral agents remains an important motivation in the search for new natural products with relevant biological activity. Pseudodesmin A and B are both mainly active against Gram positive bacteria such as VRE and MRSA. However, they are generally less potent and their inhibition spectrum is not as broad as standard antibiotics such as vancomycin. They also do not possess any noteworthy antifungal, antiviral or cytostatic activity. Pseudodesmin A and B are very similar to a collection of CLPs known as the viscosin group ${ }^{1}$ (Figure 4). A prominent distinction with all but one (viscosinamide) of the other members in this group is that they have a glutamine rather than a glutamic acid at position 2. It can be noted that pseudodesmin A differs from WLIP only by this D-Glu/D-Gln substitution. Pseudodesmin A can thus be considered as WLIPamide. Compared to viscosinamide, it only differs with respect to the stereochemistry of the Leu at position 5, being D rather than L. With an L-Val at position 9 pseudodesmin B differs by at least two substitutions from any previously known viscosin group member: WLIP (Ile9 and Glu2) and viscosinamide (L-Leu5 and Ile9). Only one other member, massetolide E, features an L-Val9, however, it has an L-Leu rather than a D-Leu at position 5 and a D-Glu instead of D-Gln.

Viscosin has been described by Kochi et $\mathrm{al}^{8}$ to have no effect against most of the Gram positive and Gram negative bacteria that they tested. Later, both viscosin and the massetolides were reported to possess significant activity against Mycobacterium tuberculosis and Mycobacterium aviumintracellulare, but not against E. coli and S. aureus ${ }^{6}$. The latter is a significant difference with the pseudodesmins, which could possibly be correlated with the opposite stereochemistry of the Leu5 residue. Viscosinamide has been found to be mainly active against plant pathogens such as Rhizoctonia solani and Pythium ultimum ${ }^{4,13}$. While no antifungal activity for the pseudodesmins was observed, the pseudophomins have been found to be responsible for the antifungal activity of $P$. fluorescens ${ }^{7}$. Because the latter compounds were not confronted against the same pathogens used here, a direct comparison can unfortunately not be made. WLIP was initially found to inhibit the brown blotch disease in Agaricus bisporus caused by Pseudomonas tolaasii ${ }^{15}$ and only later subjected to a more thorough biological screening against fungi and bacteria ${ }^{12}$. It was shown to display the same properties as the pseudodesmins in that it is mainly active against Gram positive but not against Gram 
negative bacteria. $C$. albicans, $C$. neoformans and $E$. coli, the only common pathogens in the WLIP and pseudodesmin screenings, were also found not to be inhibited by WLIP.

\subsection{Conformation of pseudodesmin A and comparison to other CLPs}

From the alignment of sequences in the viscosin group (Figure 4), two subsets can be distinguished depending on whether Leu5 has an L (viscosin, viscosinamide and massetolides A-H) or D (WLIP, the pseudophomins and the pseudodesmins) configuration. This is motivated by the fact that other variations affect the nature of the side chains rather than the backbone. Since three dimensional structures have only been determined for the D-Leu type viscosin members, the structural impact of the $\mathrm{D} / \mathrm{L}$ variation can unfortunately not yet be assessed. Given the high sequence similarity within the D-Leu subset, it is of no surprise that the crystal structure of pseudodesmin A is practically identical to those of WLIP ${ }^{16}$ and the pseudophomins ${ }^{17}$. In all cases, the RMSD between the oligopeptide backbone and Thr3 side chain atom coordinates (29 atoms) is smaller than $0.03 \AA$. Consequently, the short $\alpha_{\mathrm{L}^{-}}$ helix present in pseudodesmin A is also present in these structures even though it was never recognized as such before. An NMR solution structure has been reported for WLIP as well ${ }^{5}$, which was described to be significantly different from the crystal structure. Since the coordinates of this structure are not available, further comparisons cannot be made.

Helical structures in cyclic lipodepsipeptides have also been described outside the viscosin group. Amphisin ${ }^{18}$ and tensin ${ }^{19}$ (Figure 4) are CLPs very similar to the viscosin group, but have a ring structure built out of 9 residues instead of 7 . There are some substitutions of residues, but the overall pattern of hydrophobic and hydrophilic amino acids and D and L chirality is maintained. A crystal structure for both these CLPs has been reported and both possess an $\alpha_{\mathrm{L}}$-helix of equal number of residues to pseudodesmin A, while the extra residues are accommodated in the C-terminal loop. The RMSD of the backbone of this helix to the pseudodesmin A structure measured starting from the amide of residue 2 to the carbonyl of residue 5 ( 12 atoms) is only $0.15 \AA$ for amphisin and $0.12 \AA$ for tensin. Other CLPs are also described to contain $\alpha$-helices, including tolaasin, fuscopeptin and syringopeptin ${ }^{1}$. It appears therefore that the $\alpha$-helix is a common structure among many CLPs, suggesting a role of importance for their biological function.

An important feature of the pseudodesmin A structure is that it is amphipatic. Indeed, all hydrophobic and hydrophilic residues in the sequence occur at positions that arrange their side chains on opposite sides of the molecule (Figure 5). This includes the three-residue loop region where the LD-L stereochemistry allows the hydrophilic D-Ser8 side chain to be oriented towards the opposite side of the structure with respect to the hydrophobic L-Leu7 and L-Ile9 side chains. All together, this creates a large hydrophobic surface, comprised of all Leu, Ile and Val side chains. A smaller hydrophilic surface includes both Ser residues and the Gln residue side chains. The conservation of hydrophobic and hydrophilic residues within the viscosin group and the helical part of amphisin and tensin (Figure 4) suggests that this amphipaticity is maintained between the different compounds and that it plays an important role in their function.

It has been hypothesized that the biological function and antibiotic mechanism of CLPs is related to the formation of passive transport ion channels in the cellular membranes. These will seriously destabilize the microorganism's metabolism by disturbing the ion concentrations in the cytoplasm. Within the viscosin group this has been postulated for viscosinamide, which is believed to induce $\mathrm{Ca}^{2+}$ transporting pores to inhibit fungal growth ${ }^{13}$. Furthermore, WLIP has been shown to insert itself within model membranes ${ }^{20}$, while its pore forming capability was demonstrated on erythrocytes using osmotic protectants ${ }^{12}$. The observed properties of pseudodesmin A are in agreement with such behaviour. The fact that the compound is practically water insoluble together with the high degree of hydrophobic side chains and the fatty acid moiety makes an insertion into the apolar membrane plausible. The amphipatic nature of the molecule suggests a model for pore formation that involves the formation of reverse type micelles inside the membrane. The molecules pack together with their hydrophilic surfaces towards each other while extending the hydrophobic surfaces outward to minimize the hydrophobic-hydrophilic contacts with the environment. Independent of the exact supramolecular structure that will be formed, these reverse micelles would be able to span the membrane, allowing ions to be transported through the hydrophilic pore created. This principle has been described previously, for instance for syringomycin ${ }^{21}$. 


\section{Experimental}

\subsection{Culture, isolation and purification of pseudodesmin A and B}

The original Pseudomonas tolaassii strain was collected from the skin of a black belly salamander (Desmognathus quadramaculatus) and was a gift from R. Austin (Plethodon Research, L.L.C., 1590 Double Springs Road, Demorest, GA 30535, USA). Isolation, preliminary characterization and biological screening have been described previously ${ }^{22}$.

Following fermentation of the bacterium using standard procedures, the fermentation broth was extracted with ethyl acetate, dried over $\mathrm{MgSO}_{4}$ and concentrated in vacuo. The residue was redissolved in acetone and a first purification was done using a normal phase open column (Kieselgel 60, 230-400 mesh ASTM, Merck) with following eluents: hexane/acetone (8/2), hexane/acetone (1/1), acetone, and ethanol. The fractions collected after eluting with acetone contained the bioactive material. After concentrating, the compound was brought on a preparative TLC (PLC) plate (Silicagel 60, 20x20 cm, 0.5mm layer thickness, Merck) and eluted with dichloromethane/methanol (96/4). The fractions were scraped off and the molecules extracted from the silica with methanol. The band between $R_{\mathrm{f}}$ values 0 and 0.08 contained the antibacterial molecules. Preliminary LC-MS analysis of this fraction showed the strong presence of a molecule with protonated mass $[\mathrm{M}+\mathrm{H}]^{+}$of 1125.3 Dalton. The LC-MS consisted of a Waters 2690 HPLC with Photodiode Array Detector (Waters 996) coupled to a Micromass Q-TOF 2 mass spectrometer. The column used was from Beckman (Ultrasphere; C-18; $5 \mu \mathrm{m}, 150 \times 4.6 \mathrm{~mm}$ ) with guard column $7.5 \times 4.6 \mathrm{~mm}$, packed with the same material; eluent: acetonitrile/ $10 \mathrm{mM} \mathrm{NH} \mathrm{NHAc}_{4} \mathrm{OAn}$ water with $0.1 \%$ TFA $(60 / 40$; flow: $1.5 \mathrm{ml} / \mathrm{min})$; detection: $210 \mathrm{~nm}$; retention time: 14.4 minutes (peudodesmin A) or 11.1 minutes (pseudodesmin B), measured from the UV chromatograms. MS spectra were taken in positive electrospray ionization mode with capillary voltage set at $2.5 \mathrm{kV}$, the cone voltage at $60 \mathrm{~V}$, a collision energy of $15 \mathrm{eV}$, the microchannel plate at $2150 \mathrm{~V}$, the source temperature at $100^{\circ} \mathrm{C}$ and the desolvation temperature at $250^{\circ} \mathrm{C}$. The fragmentation of the parent ion $\left(\mathrm{M}+\mathrm{H}^{+}\right)$was studied via MS/MS analysis in positive electrospray ionization mode with a capillary voltage of $2 \mathrm{kV}$, the cone voltage at $60 \mathrm{~V}$ and the collision energy at $41 \mathrm{eV}$. The rest of the parameters were the same as mentioned above. For further analysis, both compounds, pseudodesmin A and B, were obtained in larger quantities as white solids, with yields of $260 \mathrm{mg}$ and $27 \mathrm{mg}$ respectively, which corresponds to $0.163 \%$ and $0.0169 \%$ of weight compared to the collected freeze dried biological material. This is fully described in the supplementary data.

\subsection{Biological screening}

The screening for biological activity involved a selection of pathogens, including bacteria (Enterococcus faecalis ATCC 29212/LMG 8222, vancomycin resistant Enterococcus (VRE) ATCC 700221, Staphylococcus aureus ATCC 29213/LMG 10147, methicillin resistant S. aureus (MRSA) ATCC 33591/LMG 16217, Pseudomonas aeruginosa ATCC 27853/LMG 6395, Salmonella typhimurium ATCC 700408/LMG 16217, Clostridium perfringens ATCC 13124, Escherichia coli ATCC 25922), yeasts (Candida albicans IHEM 10248 ATCC 24433 and Cryptococcus neoformans IHEM 9558 ATCC 90112) and one mould (Trichophyton mentagrophytes IHEM 10342/ATCC 9533). C. perfringens was obtained from Oxoid as a Culti-Loop culture and grown in Anaerobe Basal broth (Oxoid, CM 957), while the other microorganisms were obtained from the Belgian Coordinated Collections of Microorganisms (BCCM).

All the bacteria were grown for 18 hours in Mueller-Hinton broth (MHB, Oxoid, CM 405). Instant suspensions were prepared in $5 \mathrm{ml}$ quantities of sterile saline. After standardization according to the $0.5 \mathrm{McFarland}$ standard, the suspensions were further diluted to a final inoculum of approximately $5 \cdot 10^{5} \mathrm{CFU} / \mathrm{ml}$.

For both the yeasts, a RPMI 1640 broth supplemented with $0.3 \mathrm{~g} / 1$ glutamine and $34.6 \mathrm{~g} / \mathrm{l} 3-(\mathrm{N}-$ morpholino)propanesulfonic acid (MOPS-buffer) without bicarbonate was used. The yeasts were then sub-cultured at $35^{\circ} \mathrm{C}$ onto Sabouraud dextrose agar and passaged twice to ensure purity and viability. Five colonies of $\geq 1 \mathrm{~mm}$ diameter from 24 hour (C. albicans) or 48 hour (C. neoformans) old cultures 
were picked and suspended in $5 \mathrm{ml}$ of sterile $0.85 \%$ saline. The suspension cell densities were then standardized to a $0.5 \mathrm{McF}$ arland standard with sterile saline by measuring the transmittance of a spectrophotometer at $530 \mathrm{~nm}$. The obtained suspensions of $1-5 \cdot 10^{6}$ cells per ml were further diluted to obtain a final inoculum of $1-5 \cdot 10^{3} \mathrm{CFU} / \mathrm{ml}$.

For the mould, a seven days old culture was covered with approximately $1 \mathrm{ml}$ of sterile $0.85 \%$ saline. A suspension was made and one drop of Tween 20 was added. The resulting mixture of spores and hyphal fragments was transferred to a sterile tube and allowed to settle. The upper homogeneous suspension was collected and mixed. The densities of these spore suspensions were then adjusted to an optical density (OD) of $75 \%$ transmittance at $530 \mathrm{~nm}$. The obtained suspension was further diluted in RPMI 1640 broth to obtain a final inoculum of $4 \cdot 10^{3}$ to $5 \cdot 10^{4} \mathrm{CFU} / \mathrm{ml}$.

The minimum inhibitory concentration (MIC) was determined for both pseudodesmins on every pathogen next to a quality positive control compound ${ }^{23}$, being for the bacteria either vancomycin (Fluka/BioChemika 94747) or gentamycin (Fluka/Biochemika 48760) and for the yeasts and the mould amphotericin B (Fluka/Biochemika 10047). 2500 ppm solutions in DMSO were obtained of all test chemicals and further diluted 10-fold in a 11:1 demineralized water:DMSO mixture.

A robotic Bioscreen apparatus (Labsystems, Finland) operating under Biolink software was used which measures the change in OD (using white light, Wide Band) of the broth culture. Each of the 100 well honeycomb plates (Labsystems) contained $225 \mu \mathrm{l}$ MHB (RPMI 1640, $0.3 \mathrm{~g} / \mathrm{l}$ glutamine and 34.6 $\mathrm{g} / \mathrm{l}$ MOPS-buffer without bicarbonate for the mould) and $25 \mu \mathrm{l}$ of the solvent (negative control), testchemical dilution, or positive control. The inoculum was added to the broth, except for the blank tests. The bacteria, $C$. albicans, $C$. neoformans and the mould were incubated for 16, 24, 48 hours and 5 days respectively at $35^{\circ} \mathrm{C}\left(25^{\circ} \mathrm{C}\right.$ for the mould), with every 20 minutes an OD measurement after medium shaking. $C$. perfringens was incubated under an anaerobic environment purged with $\mathrm{CO}_{2}$.

Each test was repeated 5 times and the average was calculated. A blank test was performed with only the test chemical and MHB in the well and the difference $\Delta$ between the sample and blank areas was calculated. Negative control incubation tests were performed in an analogous manner except for the absence of test chemicals, resulting in an obtained value $\Delta_{\mathrm{NC}}$. The percent of growth was then calculated as $\left(\Delta / \Delta_{\mathrm{NC}}\right) \times 100 \%$, which was chosen as critical parameter for the evaluation of possible activity. For the mould, instead of kinetic measurements, the difference between final and initial OD values was used. Each test was repeated 5 times and the average was calculated.

In addition, the mixture of pseudodesmin $\mathrm{A}$ and $\mathrm{B}$ was screened for antiviral and antitumor effects at the Rega Institute (K.U. Leuven) against various pathogenic viruses such as human immunodeficiency virus (HIV), herpes simplex virus (HSV), vaccinia virus (VV), varicella zoster virus (VZV) and human cytomegalovirus (CMV). Antiviral activity was determined as the effective compound concentration $\left(\mathrm{EC}_{50}\right)$ required to inhibit by $50 \% \mathrm{HIV}$-induced cytopathicity in human CEM cell cultures, HSV- and VV-induced cytopathicity in human embryo fibroblast $\mathrm{E}_{6} \mathrm{SM}$ cell cultures, VZVinduced plaque formation in human embryonic lung (HEL) cell cultures and as the concentration $\left(\mathrm{IC}_{50}\right)$ required to inhibit CMV-induced plaque formation by $50 \%$ using HEL cells. Antitumor activity was determined via the inhibitory effects on the proliferation of murine leukemia cells (L1210/0), murine mammary carcinoma cells (FM3A/0) and human T-lymphocyte cells (Molt4/C8, CEM/0).

\subsection{LC-MS analysis of the amino acid composition}

For this analysis, $6.6 \mathrm{mg}$ of pseudodesmin A was hydrolyzed by dissolving it in $6.6 \mathrm{ml} 6 \mathrm{M} \mathrm{HCl}$ together with $136 \mathrm{mg}$ phenol for 20 hours at $110^{\circ} \mathrm{C}$. After solvent evaporation in vacuo, the residue was dissolved in $5.28 \mathrm{ml}$ of $\mathrm{H}_{2} \mathrm{O}$ and $2.29 \mathrm{ml}$ of a $3.7 \mathrm{mM}$ solution of Marfey's reagent ${ }^{14}$ in acetone to which $528 \mu \mathrm{l}$ of $1 \mathrm{M} \mathrm{NaHCO}_{3}$ were added to derivatize the free amino acids formed. After stirring this mixture for one hour at $40^{\circ} \mathrm{C}, 264 \mu \mathrm{l}$ of a $2 \mathrm{M} \mathrm{HCl}$ solution was added and the solvent was evaporated. The residue was dissolved in $8.8 \mathrm{ml}$ DMSO and $60 \mu \mathrm{l}$ of this solution was diluted to $200 \mu \mathrm{l}$ with a 40/60 mixture of acetonitrile/ $\mathrm{NH}_{4} \mathrm{OAc} 5 \mathrm{mM}$. Standard solutions of L- and D-amino acids derivatized with Marfey's reagent were prepared by adding $50 \mu 150 \mathrm{mM}$ amino acid aqueous solution to $100 \mu \mathrm{l}$ of $3.7 \mathrm{mM}$ Marfey's reagent in acetone and $20 \mu \mathrm{l}$ of $1 \mathrm{M} \mathrm{NaHCO}_{3}$. After one hour at $40^{\circ} \mathrm{C}, 10 \mu \mathrm{l}$ of $2 \mathrm{M}$ $\mathrm{HCl}$ was added, the solvent was removed in vacuo and the residue was dissolved in $500 \mu \mathrm{DMSO}$. This was done separately for several amino acids. By taking $30 \mu \mathrm{l}$ of every solution, the following mixtures were made and diluted to $200 \mu \mathrm{l}$ with a $40 / 60$ mixture of acetonitrile/ $\mathrm{NH}_{4} \mathrm{OAc} 5 \mathrm{mM}$ : D-Leu 
+ D-Val + D-Thr, L-Leu + L-Val + L-Thr, D-Ile + D-Ser, L-Ile + L-Ser, D-Glu, L-Glu, D-allo-Thr, L-

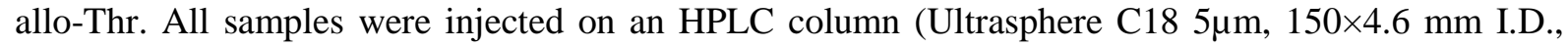
fitted with a precolumn with the same stationary phase, $7.5 \times 4.6 \mathrm{~mm}$ I.D.) hyphenated to a UV-detector operating at a wavelength of $350 \mathrm{~nm}$ for peak integration and a Q-TOF mass spectrometer using negative mode electrospray as ionization technique. The mobile phase, acetonitrile/ $\mathrm{NH}_{4} \mathrm{OAc} 5 \mathrm{mM}$, was linearly changed from a 10/90 to 28/72 mixture over a time span of 36 minutes.

\subsection{NMR Spectroscopy}

All NMR measurements were performed on either a Bruker DRX spectrometer operating at 500.13 $\mathrm{MHz}$ and $125.76 \mathrm{MHz}$ for the ${ }^{1} \mathrm{H}$ and ${ }^{13} \mathrm{C}$ frequency respectively, or a Bruker Avance II spectrometer operating at $700.13 \mathrm{MHz}, 176.05 \mathrm{MHz}$ and $70.94 \mathrm{MHz}$ for ${ }^{1} \mathrm{H},{ }^{13} \mathrm{C}$ and ${ }^{15} \mathrm{~N}$ respectively. In both cases, a ${ }^{1} \mathrm{H},{ }^{13} \mathrm{C},{ }^{15} \mathrm{~N}$ TXI-Z probe was used. The sample temperature was set to $298.0 \mathrm{~K}$. High quality NEHP5-7 (New Era Ent. Inc) NMR tubes were used. Acetonitrile-d3 (99.96\%) was purchased from Eurisotop, 2D spectra measured for structure elucidation include gradient selected phase sensitive DQF-COSY, TOCSY with a $90 \mathrm{~ms}$ MLEV-17 spinlock, NOESY with mixing times ranging between $100 \mathrm{~ms}$ and $300 \mathrm{~ms}$, gradient selected ${ }^{1} \mathrm{H}_{-}{ }^{13} \mathrm{C}$ gHSQC and ${ }^{1} \mathrm{H}_{-}{ }^{15} \mathrm{~N}$ gHSQC and gradient selected ${ }^{1} \mathrm{H}-{ }^{13} \mathrm{C}$ gHMBC. Standard pulse sequences as present in the Bruker library were used throughout ${ }^{24}$. Typically, 4096 data points were sampled in the direct dimension for 512 data points in the indirect dimension, with the spectral width respectively set to $11 \mathrm{ppm}, 170 \mathrm{ppm}$ and $80 \mathrm{ppm}$ along the ${ }^{1} \mathrm{H},{ }^{13} \mathrm{C}$ and ${ }^{15} \mathrm{~N}$ dimension. The ${ }^{1} \mathrm{H}_{-}{ }^{13} \mathrm{C}$ gHMBC was measured with an $88 \mathrm{ppm}{ }^{13} \mathrm{C}$ spectral width centred on the carbonyl chemical shift region. For 2D processing, the spectra were zero filled until a $4096 \times 2048$ real data matrix. Before Fourier transformation, all spectra were multiplied with a squared cosine bell function in both dimensions or sine bell in the direct dimension for the gHMBC. The ${ }^{1} \mathrm{H}$ and ${ }^{13} \mathrm{C}$ chemical shifts are referenced against internal TMS, while the ${ }^{15} \mathrm{~N}$ chemical shift was referenced indirectly to $\mathrm{MeNO}_{2}$ according to IUPAC guidelines ${ }^{25}$. Scalar couplings were obtained from the Gaussian resolution enhanced $1 \mathrm{D}{ }^{1} \mathrm{H}$ spectrum.

\subsection{Crystal growth and X-Ray structure determination}

Following extensive screening, colourless needle-like crystals of pseudodesmin A of sufficient quality for X-ray diffraction studies were finally obtained by slow evaporation from a concentrated solution in acetonitrile. X-ray data were collected on an Oxford Diffraction Gemini R Ultra diffractometer using monochromatic $\mathrm{Cu} \mathrm{K \alpha}$ radiation. The data were processed using the CrysAlis package (Oxford Diffraction (2007) CrysAlis CCD and CrysAlis RED, versions 1.171.32.5, Oxford Diffraction Ltd, Abingdon, Oxfordshire, England). The structure was solved with Sir92 ${ }^{26}$ and refined against low temperature data using full-matrix least-squares refinement within SHELXL97 ${ }^{27,28}$ as available in the PLATON suite ${ }^{29}$. All $\mathrm{H}$ atoms were calculated geometrically and restrained to ride on their parent atoms. A correction for diffuse effects due to the inclusion of disordered solvent molecules in the crystal structure was made using the SQUEEZE option of PLATON. The total potential solvent volume per unit cell was calculated to be $261 \AA^{3}$ ( $4 \%$ of the cell volume).

\section{ACKNOWLEDGEMENTS}

The Fund for Scientific Research - Flanders (FWO-Vlaanderen) is gratefully acknowledged for a PhD fellowship to D.S. and various equipment grants (G.0365.03, G.0064.07) to J.C.M. C.M. thanks the Belgian National Fund for Scientific Research for her postdoctoral researcher position. The 700 $\mathrm{MHz}$ equipment of the Interuniversitary NMR Facility was financed by Ghent University, the Free University of Brussels (VUB) and the University of Antwerp via the 'Zware Apparatuur' Incentive of the Flemish Government. This research is supported by the NMR Scientific Research Community of the FWO. Prof. Dr. Pat Sandra and Dr. Alberto dos Santos Pereira of the RIC are most gratefully thanked for the high resolution mass spectrometry analysis. Dr. Rick Austin (Plethodon Inc) is gratefully acknowledged for the gift of a sample of $P$. tolaasii.

\section{REFERENCES}


1. $\quad$ Nybroe, O.; Sorensen, J. In Pseudomonas Volume III- Macromolecules; Ramos, J.-L. Ed.; Kluwer Academic/Plenum Publishers: New York, 2004; pp. 147-172.

2. Raaijmakers, J. M.; de Bruijn, I.; de Kock, M. J. D. Mol. Plant-Microbe Interact. 2006, 19, 699-710.

3. Hiramoto, M.; Okada, K.; Nagai, S. Tetrahedron Lett. 1970, 1087-90.

4. Nielsen, T. H.; Christophersen, C.; Anthoni, U.; Sorensen, J. J. Appl. Microbiol. 1999, 87, 8090.

5. Mortishire-Smith, R. J.; Nutkins, J. C.; Packman, L. C.; Brodey, C. L.; Rainey, P. B.; Johnstone, K.; Williams, D. H. Tetrahedron 1991, 47, 3645-3654.

6. $\quad$ Gerard, J.; Lloyd, R.; Barsby, T.; Haden, P.; Kelly, M. T.; Andersen, R. J. J. Nat. Prod. 1997, 60, 223-229.

7. $\quad$ Pedras, M. S. C.; Ismail, N.; Quail, J. W.; Boyetchko, S. M. Phytochemistry 2003, 62, 11051114.

8. $\quad$ Kochi, M.; Weiss, D. W.; Pugh, L. H.; Groupé, V. Bacteriological Proceedings 1951, 1, 2930 .

9. Saini, H. S.; Barragan-Huerta, B. E.; Lebron-Paler, A.; Pemberton, J. E.; Vazquez, R. R.; Burns, A. M.; Marron, M. T.; Seliga, C. J.; Gunatilaka, A. A. L.; Maier, R. M. J. Nat. Prod. 2008, 71, 1011-1015.

10. Laycock, M. V.; Hildebrand, P. D.; Thibault, P.; Walter, J. A.; Wright, J. L. C. J. Agric. Food. Chem. 1991, 39, 483-489.

11. de Souza, J. T.; de Boer, M.; de Waard, P.; van Beek, T. A.; Raaijmakers, J. M. Appl. Environ. Microbiol. 2003, 69, 7161-7172.

12. Lo Cantore, P.; Lazzaroni, S.; Coraiola, M.; Dalla Serra, M.; Cafarchia, C.; Evidente, A.; Iacobellis, N. S. Mol. Plant-Microbe Interact. 2006, 19, 1113-1120.

13. Thrane, C.; Olsson, S.; Nielsen, T. H.; Sorensen, J. FEMS Microbiol. Ecol. 1999, 30, 11-23.

14. Marfey, P. Carlsberg Res. Commun. 1984, 49, 591-596.

15. Soler-Rivas, C.; Arpin, N.; Olivier, J. M.; Wichers, H. J. J. Appl. Microbiol. 1999, 86, 635641.

16. Han, F. S.; Mortishire-Smith, R. J.; Rainey, P. B.; Williams, D. H. Acta Crystallogr., Sect. C: Cryst. Struct. Commun. 1992, 48, 1965-1968.

17. Quail, J. W.; Ismail, N.; Pedras, M. S. C.; Boyetchko, S. M. Acta Crystallogr., Sect. C: Cryst. Struct. Commun. 2002, 58, o268-o271.

18. Sorensen, D.; Nielsen, T. H.; Christophersen, C.; Sorensen, J.; Gajhede, M. Acta Crystallogr., Sect. C: Cryst. Struct. Commun. 2001, 57, 1123-1124.

19. Henriksen, A.; Anthoni, U.; Nielsen, T. H.; Sorensen, J.; Christophersen, C.; Gajhede, M. Acta Crystallogr., Sect. C: Cryst. Struct. Commun. 2000, 56, 113-115.

20. Coraiola, M.; Lo Cantore, P.; Lazzaroni, S.; Evidente, A.; Lacobellis, N. S.; Dalla Serra, M. Biochim. Biophys. Acta: Bomembranes 2006, 1758, 1713-1722.

21. Hutchison, M. L.; Tester, M. A.; Gross, D. C. Mol. Plant-Microbe Interact. 1995, 8, 610-620.

22. Austin, R. M., Jr., Van hemel, J., Sas, B., and Vanderkerckhove, J., Patent application (Publication number WO/2002/078720, 2002, to be found at http://www.wipo.int).

23. National Committee for Clinical Laboratory Standards (1997) Methods for Dilution Antimicrobial Susceptibility Tests for Bacteria that Grow Aerobically-Fourth Edition: Approved Standard M7-A4. NCCLS. Wayne, PA, USA.

24. $\quad$ Berger, S.; Braun, S. 200 and More NMR Experiments: A practical Course, $3^{\text {rd }}$ ed.; John Wiley and Sons Ltd Weinheim, 2004.

25. Harris, R. K.; Becker, E. D.; De Menezes, S. M. C.; Goodfellow, R.; Granger, P. Pure Appl. Chem. 2001, 73, 1795-1818.

26. Altomare, A.; Cascarano, G.; Giacovazzo, C.; Guagliardi, A. J. Appl. Crystallogr. 1993, 26, 343-350.

27. Sheldrick, G. Acta Crystallogr. A 1984, 40, C440-C440.

28. Vandersluis, P.; Spek, A. L. Acta Crystallogr. A 1990, 46, 194-201.

29. Spek, A. L. J. Appl. Crystallogr. 2003, 36, 7-13. 
Table 1 Antibacterial and antifungal activity

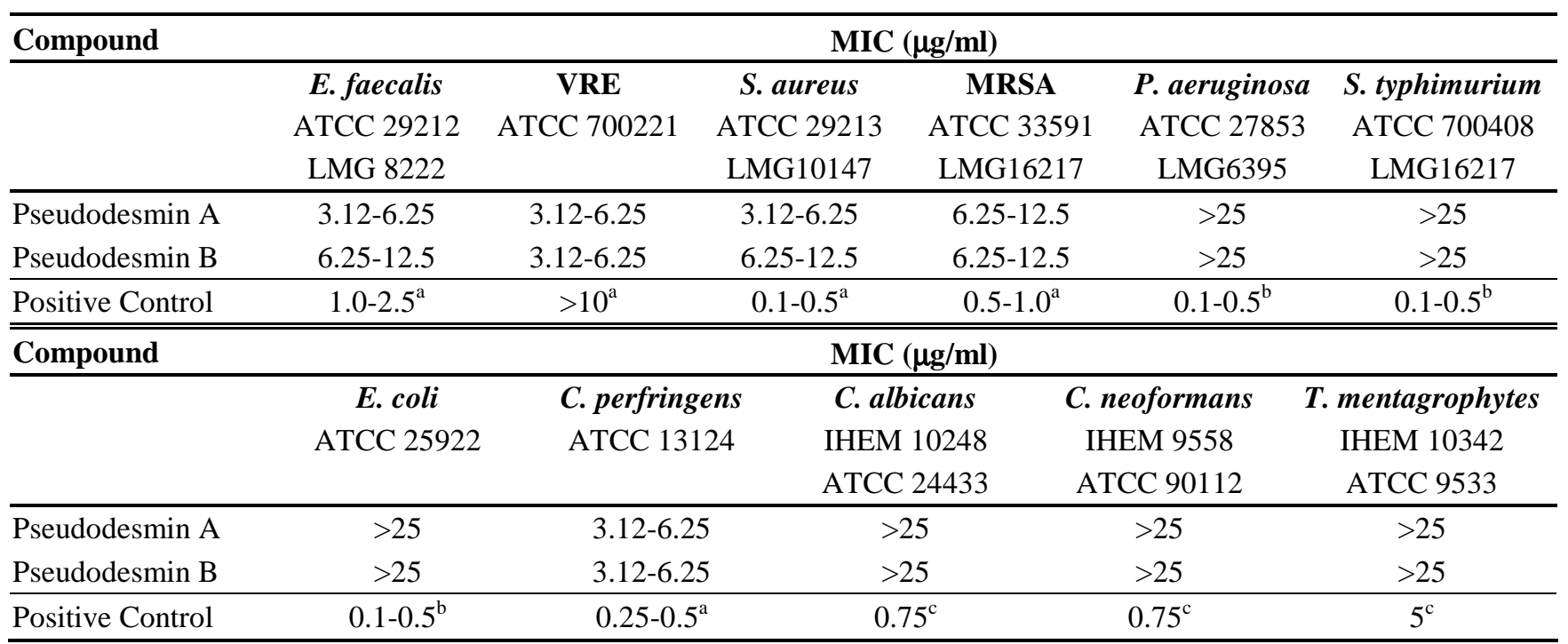

The lower value is the highest concentration where inhibition was detected, the higher value is the lowest concentration where no inhibition was detected. The maximum concentration tested was 25 $\mu \mathrm{g} / \mathrm{ml}$. MIC values of positive control compounds were determined in parallel.

${ }^{\mathrm{a}}$ vancomycin

${ }^{\mathrm{b}}$ gentamycin

${ }^{\mathrm{c}}$ amphotericin B 
Table 2 Antiviral activity and cytotoxic activity

\begin{tabular}{|c|c|c|c|c|c|c|c|}
\hline \multirow[t]{4}{*}{ Compound } & \multicolumn{7}{|c|}{$\mathrm{EC}_{50}(\mu \mathrm{g} / \mathrm{ml})$} \\
\hline & \multirow{3}{*}{$\begin{array}{c}\text { HIV-1 } \\
\left(\text { III }_{\text {B }}\right) \\
\text { (CEM) }\end{array}$} & \multirow{3}{*}{$\begin{array}{l}\text { HIV-2 } \\
\text { (ROD) } \\
\text { (CEM) }\end{array}$} & \multirow{3}{*}{$\begin{array}{c}\text { HSV-1 } \\
(\mathrm{KOS}) \\
\left(\mathrm{E}_{6} \mathrm{SM}\right)\end{array}$} & \multirow{3}{*}{$\begin{array}{c}\text { HSV-2 } \\
(G) \\
\left(\mathrm{E}_{6} \mathrm{SM}\right)\end{array}$} & \multirow{3}{*}{$\begin{array}{c}\mathrm{VV} \\
\left(\mathrm{E}_{6} \mathrm{SM}\right)\end{array}$} & \multirow{2}{*}{\multicolumn{2}{|c|}{$\begin{array}{c}\text { VZV } \\
\text { (HEL) }\end{array}$}} \\
\hline & & & & & & & \\
\hline & & & & & & OKA & YS \\
\hline Pseudodesmin $\mathrm{A}+\mathrm{B}$ & 7.3 & 17.3 & $>16$ & $>16$ & $>16$ & 3 & 3 \\
\hline Reference value & $0.0063^{\mathrm{a}}$ & $0.0097^{\mathrm{a}}$ & $0.07^{\mathrm{b}}$ & $0.38^{\mathrm{b}}$ & $3.2^{\mathrm{c}}$ & $0.24^{\mathrm{b}}$ & $0.32^{\mathrm{b}}$ \\
\hline \multirow[t]{3}{*}{ Compound } & \multicolumn{7}{|c|}{$\mathrm{IC}_{50}(\mu \mathrm{g} / \mathrm{ml})$} \\
\hline & \multicolumn{2}{|c|}{ CMV } & L1210/0 & \multirow[t]{2}{*}{ FM3A/0 } & & $4 / \mathrm{C8}$ & \multirow[t]{2}{*}{ CEM/0 } \\
\hline & $\begin{array}{c}\text { AD-169 } \\
\text { strain }\end{array}$ & $\begin{array}{l}\text { Davis } \\
\text { strain }\end{array}$ & & & & & \\
\hline Pseudodesmin $\mathrm{A}+\mathrm{B}$ & 8 & $>5$ & 17 & 16 & & 7 & 17 \\
\hline Reference value & $1.2^{\mathrm{d}}$ & $0.6^{\mathrm{d}}$ & -- & -- & & & -- \\
\hline
\end{tabular}

Reference values of standard compounds are provided for comparison ${ }^{23}$.

${ }^{\mathrm{a}} \mathrm{AZT}$

${ }^{\mathrm{b}}$ Acyclovir

${ }^{\mathrm{c}}$ Brivudin

${ }^{\mathrm{d}}$ Ganciclovir 
Table $3 \quad{ }^{1} \mathrm{H},{ }^{13} \mathrm{C}$ and ${ }^{15} \mathrm{~N}$ NMR assignments of pseudodesmin $\mathrm{A}\left(\mathrm{CD}_{3} \mathrm{CN}, 298 \mathrm{~K}, 700 \mathrm{MHz}\right)$

\begin{tabular}{|c|c|c|c|c|c|c|c|c|c|}
\hline & & ${ }^{1} \mathrm{H} \delta[\mathrm{ppm}]$ & ${ }^{13} \mathrm{C} \delta[\mathrm{ppm}]$ & ${ }^{15} \mathrm{~N} \delta[\mathrm{ppm}]$ & & & ${ }^{1} \mathrm{H} \delta[\mathrm{ppm}]$ & ${ }^{13} \mathrm{C} \delta[\mathrm{ppm}]$ & ${ }^{15} \mathrm{~N} \delta[\mathrm{ppm}]$ \\
\hline \multirow[t]{12}{*}{$\underline{\text { HDA }}$} & & & & & $\underline{\text { Leu5 }}$ & & & & \\
\hline & $\mathrm{CO} 1$ & & 175.27 & & ${ }^{3} \mathrm{~J}_{\mathrm{HNH} \alpha} \quad 4.25 \mathrm{~Hz}$ & NH 37 & 7.72 & & -266.48 \\
\hline & $\mathrm{CH}_{2} \alpha 2$ & $2.34 / 2.43$ & 44.81 & & & $\mathrm{CH} \alpha 38$ & 3.97 & 55.74 & \\
\hline & $\mathrm{CH} \beta 3$ & 3.97 & 69.53 & & & CO 39 & & 173.62 & \\
\hline & $\mathrm{CH}_{2} \gamma 4$ & 1.47 & 38.27 & & & $\mathrm{CH}_{2} \beta 40$ & $1.51 / 1.66$ & 40.71 & \\
\hline & $\mathrm{CH}_{2} \delta 5$ & $1.31 / 1.41$ & 26.36 & & & $\mathrm{CH} \gamma 41$ & 1.77 & 25.53 & \\
\hline & $\mathrm{CH}_{2} \varepsilon 6$ & 1.29 & 30.20 & & & $\mathrm{CH}_{3} \delta 42$ & 0.87 & 23.36 & \\
\hline & $\mathrm{CH}_{2} \zeta 7$ & 1.29 & 30.20 & & & $\mathrm{CH}_{3} \delta 43$ & 0.88 & 21.34 & \\
\hline & $\mathrm{CH}_{2} \eta 8$ & 1.27 & 32.63 & & $\underline{\text { Ser6 }}$ & & & & \\
\hline & $\mathrm{CH}_{2} \theta 9$ & 1.29 & 23.44 & & ${ }^{3} \mathrm{~J}_{\mathrm{HNH} \alpha} \quad 8.47 \mathrm{~Hz}$ & NH 44 & 7.11 & & -276.91 \\
\hline & $\mathrm{CH}_{3} \mathrm{l} 10$ & 0.88 & 14.44 & & & $\mathrm{CH} \alpha 45$ & 4.32 & 56.45 & \\
\hline & OH 11 & 4.40 & & & & $\mathrm{CO} 46$ & & 171.93 & \\
\hline$\underline{\text { Leu1 }}$ & & & & & & $\mathrm{CH}_{2} \beta 47$ & $3.81 / 4.15$ & 64.80 & \\
\hline \multirow[t]{7}{*}{${ }^{3} \mathrm{~J}_{\mathrm{HNH} \alpha} \quad 5.67 \mathrm{~Hz}$} & NH 12 & 7.73 & & -253.87 & & $\mathrm{OH} \gamma 48$ & 4.98 & & \\
\hline & $\mathrm{CH} \alpha 13$ & 3.87 & 53.92 & & $\underline{\text { Leu7 }}$ & & & & \\
\hline & $\mathrm{CO} 14$ & & 175.34 & & ${ }^{3} \mathrm{~J}_{\mathrm{HNH} \alpha} \quad 6.53 \mathrm{~Hz}$ & NH 49 & 7.10 & & -260.63 \\
\hline & $\mathrm{CH}_{2} \beta 15$ & $1.65 / 1.74$ & 39.46 & & & $\mathrm{CH} \alpha 50$ & 4.13 & 54.90 & \\
\hline & $\mathrm{CH} \gamma 16$ & 1.67 & 25.46 & & & CO 51 & & 173.80 & \\
\hline & $\mathrm{CH}_{3} \delta 17$ & 0.90 & 22.16 & & & $\mathrm{CH}_{2} \beta 52$ & $1.58 / 1.88$ & 42.11 & \\
\hline & $\mathrm{CH}_{3} \delta 18$ & 0.94 & 23.21 & & & $\mathrm{CH} \gamma 53$ & 1.89 & 25.55 & \\
\hline$\underline{G \ln 2}$ & & & & & & $\mathrm{CH}_{3} \delta 54$ & 0.90 & 21.42 & \\
\hline \multirow[t]{7}{*}{${ }^{3} \mathbf{J}_{\mathrm{HNH} \alpha} \quad 3.99 \mathrm{~Hz}$} & NH 19 & 8.76 & & -260.90 & & $\mathrm{CH}_{3} \delta 55$ & 0.99 & 23.53 & \\
\hline & $\mathrm{CH} \alpha 20$ & 3.98 & 57.58 & & $\underline{\text { Ser8 }}$ & & & & \\
\hline & $\mathrm{CO} 21$ & & 176.63 & & ${ }^{3} \mathrm{~J}_{\mathrm{HNH} \alpha} \quad 9.10 \mathrm{~Hz}$ & NH 56 & 7.94 & & -273.98 \\
\hline & $\mathrm{CH}_{2} \beta 22$ & 2.02 & 26.35 & & & $\mathrm{CH} \alpha 57$ & 4.43 & 57.02 & \\
\hline & $\mathrm{CH}_{2} \gamma 23$ & 2.38 & 32.01 & & & CO 58 & & 171.86 & \\
\hline & $\operatorname{CO\delta } 24$ & & 176.15 & & & $\mathrm{CH}_{2} \beta 59$ & $3.66 / 3.86$ & 63.25 & \\
\hline & $\mathrm{NH}_{2} 25$ & $5.81 / 6.36$ & & -275.54 & & $\mathrm{OH} \gamma 60$ & 3.80 & & \\
\hline$\underline{\text { Thr3 }}$ & & & & & Ile9 & & & & \\
\hline${ }^{3} \mathrm{~J}_{\mathrm{HNH} \alpha} \quad 7.45 \mathrm{~Hz}$ & NH 26 & 8.15 & & -266.17 & ${ }^{3} \mathrm{~J}_{\mathrm{HNH} \alpha} \quad 10.70 \mathrm{~Hz}$ & NH 61 & 6.68 & & -270.70 \\
\hline \multirow[t]{4}{*}{${ }^{3} \mathrm{~J}_{\mathrm{H} \alpha \mathrm{H} \beta} \quad 10.71 \mathrm{~Hz}$} & $\mathrm{CH} \alpha 27$ & 3.99 & 61.77 & & & $\mathrm{CH} \alpha 62$ & 4.56 & 57.17 & \\
\hline & $\mathrm{CO} 28$ & & 174.33 & & & $\mathrm{CO} 63$ & & 170.12 & \\
\hline & $\mathrm{CH} \beta 29$ & 5.33 & 70.33 & & & $\mathrm{CH} \beta 64$ & 1.97 & 36.97 & \\
\hline & $\mathrm{CH}_{3} \gamma 30$ & 1.30 & 18.58 & & & $\mathrm{CH}_{3} \gamma 65$ & 0.82 & 16.28 & \\
\hline$\underline{\text { Val4 }}$ & & & & & & $\mathrm{CH}_{2} \gamma 66$ & $0.97 / 1.15$ & 25.31 & \\
\hline \multirow[t]{6}{*}{${ }^{3} \mathrm{~J}_{\mathrm{HNH} \alpha} \quad 6.30 \mathrm{~Hz}$} & NH 31 & 7.33 & & -259.73 & & $\mathrm{CH}_{3} \delta 67$ & 0.86 & 12.36 & \\
\hline & $\mathrm{CH} \alpha 32$ & 3.49 & 65.08 & & & & & & \\
\hline & CO 33 & & 174.63 & & & & & & \\
\hline & $\mathrm{CH} \beta 34$ & 2.17 & 30.02 & & & & & & \\
\hline & $\mathrm{CH}_{3} \gamma 35$ & 0.92 & 19.56 & & & & & & \\
\hline & $\mathrm{CH}_{3} \gamma 36$ & 0.95 & 21.12 & & & & & & \\
\hline
\end{tabular}


Table $4 \quad{ }^{1} \mathrm{H},{ }^{13} \mathrm{C}$ and ${ }^{15} \mathrm{~N}$ NMR assignments of pseudodesmin $\mathrm{B}\left(\mathrm{CD}_{3} \mathrm{CN}, 298 \mathrm{~K}, 700 \mathrm{MHz}\right)$

\begin{tabular}{|c|c|c|c|c|c|c|c|c|c|}
\hline & & ${ }^{1} \mathrm{H} \delta[\mathrm{ppm}]$ & ${ }^{13} \mathrm{C} \delta[\mathrm{ppm}]$ & ${ }^{15} \mathrm{~N} \delta$ [ppm] & & & ${ }^{1} \mathrm{H} \delta[\mathrm{ppm}]$ & ${ }^{13} \mathrm{C} \delta[\mathrm{ppm}]$ & ${ }^{15} \mathrm{~N} \delta[\mathrm{ppm}]$ \\
\hline \multirow[t]{12}{*}{$\underline{\text { HDA }}$} & & & & & $\underline{\text { Leu5 }}$ & & & & \\
\hline & $\mathrm{CO} 1$ & & 175.14 & & ${ }^{3} \mathrm{~J}_{\mathrm{HNH} \alpha} \quad 3.99 \mathrm{~Hz}$ & NH 37 & 7.77 & & -266.34 \\
\hline & $\mathrm{CH}_{2} \alpha 2$ & $2.35 / 2.43$ & 44.76 & & & $\mathrm{CH} \alpha 38$ & 3.97 & 55.75 & \\
\hline & $\mathrm{CH} \beta 3$ & 3.96 & 69.64 & & & CO 39 & & 173.68 & \\
\hline & $\mathrm{CH}_{2} \gamma 4$ & 1.48 & 38.29 & & & $\mathrm{CH}_{2} \beta 40$ & $1.50 / 1.67$ & 40.67 & \\
\hline & $\mathrm{CH}_{2} \delta 5$ & $1.31 / 1.40$ & 26.36 & & & $\mathrm{CH} \gamma 41$ & 1.77 & 25.54 & \\
\hline & $\mathrm{CH}_{2} \varepsilon 6$ & 1.28 & 30.12 & & & $\mathrm{CH}_{3} \delta 42$ & 0.86 & 23.36 & \\
\hline & $\mathrm{CH}_{2} \zeta 7$ & 1.28 & 30.12 & & & $\mathrm{CH}_{3} \delta 43$ & 0.87 & 21.32 & \\
\hline & $\mathrm{CH}_{2} \eta 8$ & 1.26 & 32.59 & & $\underline{\text { Ser6 }}$ & & & & \\
\hline & $\mathrm{CH}_{2} \theta 9$ & 1.29 & 23.44 & & ${ }^{3} \mathrm{~J}_{\mathrm{HNH} \alpha} \quad 8.33 \mathrm{~Hz}$ & NH 44 & 7.14 & & -276.70 \\
\hline & $\mathrm{CH}_{3} \mathrm{l} 10$ & 0.88 & 14.43 & & & $\mathrm{CH} \alpha 45$ & 4.32 & 56.47 & \\
\hline & OH 11 & 3.65 & & & & $\mathrm{CO} 46$ & & 172.03 & \\
\hline$\underline{\text { Leu1 }}$ & & & & & & $\mathrm{CH}_{2} \beta 47$ & $3.81 / 4.15$ & 64.71 & \\
\hline \multirow[t]{7}{*}{${ }^{3} \mathrm{~J}_{\mathrm{HNH} \alpha}$} & NH 12 & 7.94 & & -253.49 & & $\mathrm{OH} \gamma 48$ & 4.99 & & \\
\hline & $\mathrm{CH} \alpha 13$ & 3.89 & 53.76 & & $\underline{\text { Leu7 }}$ & & & & \\
\hline & $\mathrm{CO} 14$ & & 175.40 & & ${ }^{3} \mathbf{J}_{\mathrm{HNH} \alpha} \quad 6.23 \mathrm{~Hz}$ & NH 49 & 7.11 & & -260.54 \\
\hline & $\mathrm{CH}_{2} \beta 15$ & $1.66 / 1.74$ & 39.42 & & & $\mathrm{CH} \alpha 50$ & 4.14 & 54.86 & \\
\hline & $\mathrm{CH} \gamma 16$ & 1.67 & 25.45 & & & CO 51 & & 173.88 & \\
\hline & $\mathrm{CH}_{3} \delta 17$ & 0.90 & 22.15 & & & $\mathrm{CH}_{2} \beta 52$ & $1.61 / 1.89$ & 41.90 & \\
\hline & $\mathrm{CH}_{3} \delta 18$ & 0.93 & 23.25 & & & $\mathrm{CH} \gamma 53$ & 1.88 & 25.56 & \\
\hline$\underline{G \ln 2}$ & & & & & & $\mathrm{CH}_{3} \delta 54$ & 0.90 & 21.45 & \\
\hline \multirow[t]{7}{*}{${ }^{3} \mathrm{~J}_{\mathrm{HNH} \alpha}$} & NH 19 & 8.78 & & -260.95 & & $\mathrm{CH}_{3} \delta 55$ & 0.98 & 23.42 & \\
\hline & $\mathrm{CH} \alpha 20$ & 3.97 & 57.62 & & $\underline{\text { Ser8 }}$ & & & & \\
\hline & $\mathrm{CO} 21$ & & 176.68 & & ${ }^{3} \mathbf{J}_{\mathrm{HNH} \alpha} \quad 8.96 \mathrm{~Hz}$ & NH 56 & 7.95 & & -273.86 \\
\hline & $\mathrm{CH}_{2} \beta 22$ & 2.01 & 26.56 & & & $\mathrm{CH} \alpha 57$ & 4.44 & 57.10 & \\
\hline & $\mathrm{CH}_{2} \gamma 23$ & 2.37 & 32.14 & & & CO 58 & & 172.02 & \\
\hline & $\operatorname{CO\delta } 24$ & & 176.09 & & & $\mathrm{CH}_{2} \beta 59$ & $3.66 / 3.86$ & 63.29 & \\
\hline & $\mathrm{NH}_{2} 25$ & $5.82 / 6.42$ & & -275.49 & & $\mathrm{OH} \gamma 60$ & 3.83 & & \\
\hline \multicolumn{2}{|l|}{ Thr3 } & & & & $\underline{\text { Val9 }}$ & & & & \\
\hline${ }^{3} \mathrm{~J}_{\mathrm{HNH} \alpha} \quad 7.14 \mathrm{~Hz}$ & NH 26 & 8.20 & & -266.14 & ${ }^{3} \mathbf{J}_{\mathrm{HNH} \alpha} \quad 10.01 \mathrm{~Hz}$ & NH 61 & 6.71 & & -271.43 \\
\hline \multirow[t]{4}{*}{${ }^{3} \mathrm{~J}_{\mathrm{H \alpha H} \beta} \quad 10.68 \mathrm{~Hz}$} & $\mathrm{CH} \alpha 27$ & 3.99 & 61.84 & & & $\mathrm{CH} \alpha 62$ & 4.52 & 57.07 & \\
\hline & $\mathrm{CO} 28$ & & 174.34 & & & CO 63 & & 170.15 & \\
\hline & $\mathrm{CH} \beta 29$ & 5.33 & 70.29 & & & $\mathrm{CH} \beta 64$ & 2.23 & 30.18 & \\
\hline & $\mathrm{CH}_{3} \gamma 30$ & 1.30 & 18.64 & & & $\mathrm{CH}_{3} \gamma 65$ & 0.72 & 17.21 & \\
\hline$\underline{\text { Val4 }}$ & & & & & & $\mathrm{CH}_{2} \gamma 66$ & 0.82 & 19.49 & \\
\hline \multirow[t]{6}{*}{${ }^{3} \mathrm{~J}_{\mathrm{HNH} \alpha} \quad 6.23 \mathrm{~Hz}$} & NH 31 & 7.41 & & -259.52 & & & & & \\
\hline & $\mathrm{CH} \alpha 32$ & 3.48 & 65.10 & & & & & & \\
\hline & $\mathrm{CO} 33$ & & 174.70 & & & & & & \\
\hline & $\mathrm{CH} \beta 34$ & 2.16 & 30.02 & & & & & & \\
\hline & $\mathrm{CH}_{3} \gamma 35$ & 0.90 & 19.47 & & & & & & \\
\hline & $\mathrm{CH}_{3} \gamma 36$ & 0.95 & 21.27 & & & & & & \\
\hline
\end{tabular}

ND: not determined 
Table 5 Crystallographic parameters for pseudodesmin A

\begin{tabular}{|c|c|}
\hline \multicolumn{2}{|c|}{ Crystal data } \\
\hline Space group & Orthorhombic, $\mathrm{P} 22_{1} 2_{1} 2_{1}$ \\
\hline Unit-cell parameters $(\dot{A})$ & $\begin{array}{c}a=14.174(1), b=18.796(1), \\
c=24.423(2)\end{array}$ \\
\hline$V$ & $6506.6(8) \AA^{3}$ \\
\hline$Z$ & 4 \\
\hline$m$ & $0.71 \mathrm{~mm}^{-1}$ \\
\hline Crystal size & $0.25 \times 0.20 \times 0.10 \mathrm{~mm}$ \\
\hline \multicolumn{2}{|c|}{ Data collection } \\
\hline Measured reflections & 15350 \\
\hline Independent reflections & 8283 \\
\hline Reflections with $I>2 s(I)$ & 6185 \\
\hline$R_{\text {int }}$ & 0.04 \\
\hline \multicolumn{2}{|c|}{ Refinement } \\
\hline$R$ & 0.045 \\
\hline Reflections & 8283 \\
\hline Parameters & 737 \\
\hline$D r_{\max }$ & $0.39 \mathrm{e} \AA^{-3}$ \\
\hline$D r_{\min }$ & $-0.24 \mathrm{e} \AA^{-3}$ \\
\hline
\end{tabular}


Leu1 Gln2 Thr3 Val4 Leu5 Ser6 Leu7 Ser8 Ile9

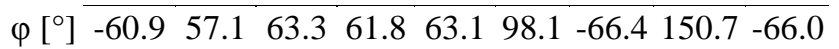

$\psi\left[{ }^{\circ}\right] \quad \begin{array}{lllllllll}122.7 & 28.5 & 40.5 & 48.6 & 31.7 & 1.0 & -50.6 & -41.2 & -6.3\end{array}$ 


\begin{tabular}{|c|c|c|c|c|}
\hline \multicolumn{5}{|c|}{ Intramolecular } \\
\hline Donor & & Acceptor & $\mathrm{d}(\mathrm{D}-\mathrm{A})[\AA \hat{A}]$ & angle $\left[{ }^{\circ}\right]$ \\
\hline Thr3 NH & - & HDA CO & 2.95 & 152.05 \\
\hline Leu5 NH & - & Leu1 CO & 3.15 & 165.35 \\
\hline Ser6 NH & - & $\mathrm{G} \ln 2 \mathrm{CO}$ & 2.82 & 149.16 \\
\hline Leu7 NH & - & Val4 CO & 3.18 & 151.21 \\
\hline Ser8 NH & - & Thr3 CO & 2.92 & 168.02 \\
\hline \multicolumn{5}{|c|}{ Intermolecular } \\
\hline \multicolumn{3}{|c|}{ Participants } & $\mathrm{d}(\mathrm{D}-\mathrm{A})[\hat{\AA}]$ & angle $\left[{ }^{\circ}\right]$ \\
\hline HDA OH & - & Ser6 $\mathrm{OH}^{\mathrm{a}}$ & 2.85 & -- \\
\hline HDA CO & - & Ser8 $\mathrm{OH}^{\mathrm{a}}$ & 2.79 & 160.87 \\
\hline Leu1 NH & - & $\mathrm{H}_{2} \mathrm{O}^{\mathrm{b}}$ & 2.83 & 164.69 \\
\hline Gln2 NH & - & Ser8 $\mathrm{CO}^{\mathrm{a}}$ & 2.85 & 164.38 \\
\hline Val4 CO & - & $\mathrm{Gln} 2 \mathrm{CONH}_{2}{ }^{\mathrm{c}}$ & 2.78 & 168.51 \\
\hline Leu5 CO & - & Ile9 $\mathrm{NH}^{\mathrm{d}}$ & 2.93 & 139.53 \\
\hline Ser6 CO & - & $\mathrm{H}_{2} \mathrm{O}^{\mathrm{e}}$ & 2.77 & 165.73 \\
\hline Leu7 CO & - & $\mathrm{H}_{2} \mathrm{O}^{\mathrm{e}}$ & 2.81 & 151.60 \\
\hline
\end{tabular}

Hydrogen bonds are considered to have a donor-acceptor bond length of at least $3.4 \AA$ and a bond angle of at least $140^{\circ}$

${ }^{a} 2^{\text {nd }}$ participant coordinates are $(x-1 / 2,3 / 2-y, 1-z)$

${ }^{\mathrm{b}} 2^{\text {nd }}$ participant coordinates are $(\mathrm{x}, \mathrm{y}, \mathrm{z})$

${ }^{\mathrm{c}} 2^{\text {nd }}$ participant coordinates are $(1 / 2-\mathrm{x}, 1-\mathrm{y}, \mathrm{z}-1 / 2)$

${ }^{\mathrm{d}} 2^{\text {nd }}$ participant coordinates are $(1-\mathrm{x}, \mathrm{y}+1 / 2,1 / 2-\mathrm{z})$

$\mathrm{e} 2^{\text {nd }}$ participant coordinates are $(x+1, y, z)$ 


\section{FIGURE LEGENDS}

Figure 1: Molecular structure of pseudodesmin A and B.

Figure 2: Crystal structure of pseudodesmin A with ellipsoids representing the B-factors.

Figure 3: Representation of the crystal structure of pseudodesmin A showing only the backbone atoms. The helix is shown as a ribbon $(\mathrm{N} \rightarrow \mathrm{C}$ from bottom to top), while the Leu7-Ile9 loop can be seen making the connection between the helix C-terminal and the Thr3 side chain.

Figure 4: Overview of analogous CLPs to pseudodesmin A and B from both the viscosin and amphisin group. The conservation of the hydrophobic and hydrophilic residue positions can clearly be observed.

Figure 5: Sphere representation of the crystal structure of pseudodesmin A to illustrate the amphipaticity, showing only the side chain atoms starting from $\mathrm{CH} \alpha$. The hydrophobic and hydrophilic sides are shown separately, while the $\alpha$-helix is aligned from bottom to top $(\mathrm{N} \rightarrow \mathrm{C})$ as indicated by the arrow. Hydrophobic side chains are coloured green, hydrophilic side chains red and the Thr3 residue salmon. The HDA residue is left out for clarity. 


\section{Figure 1}

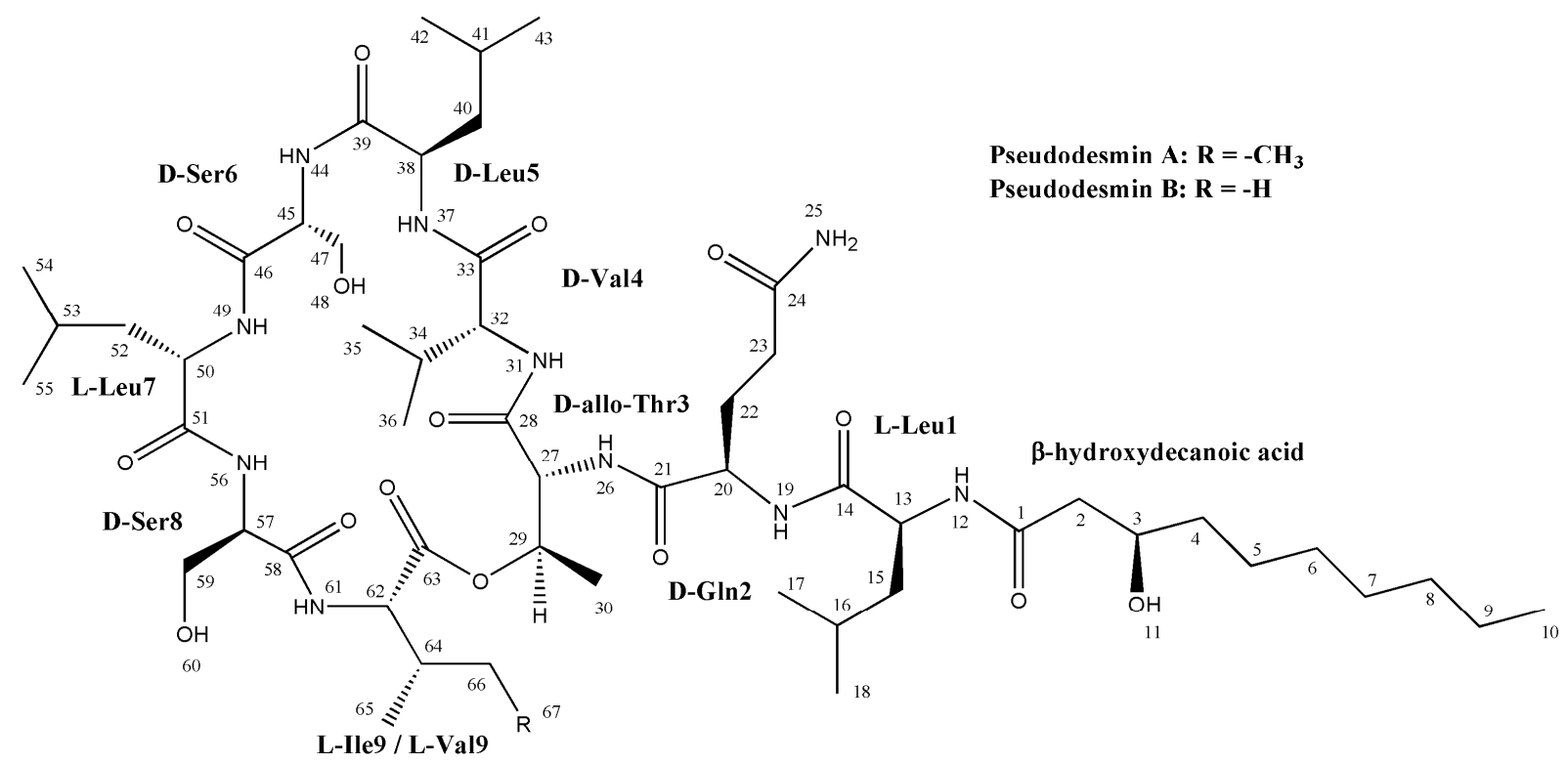


Figure 2

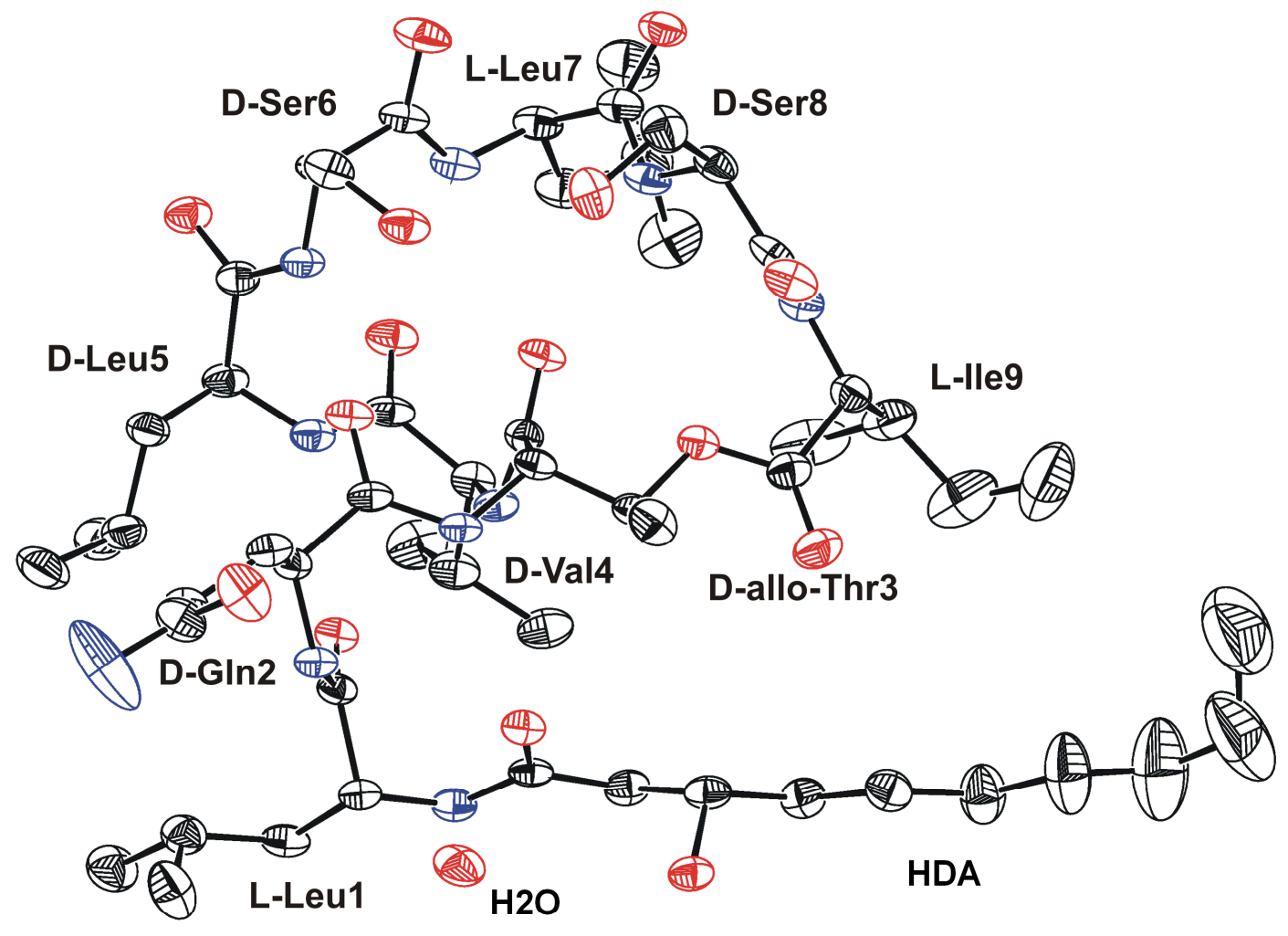


$\underline{\text { Figure } 3}$

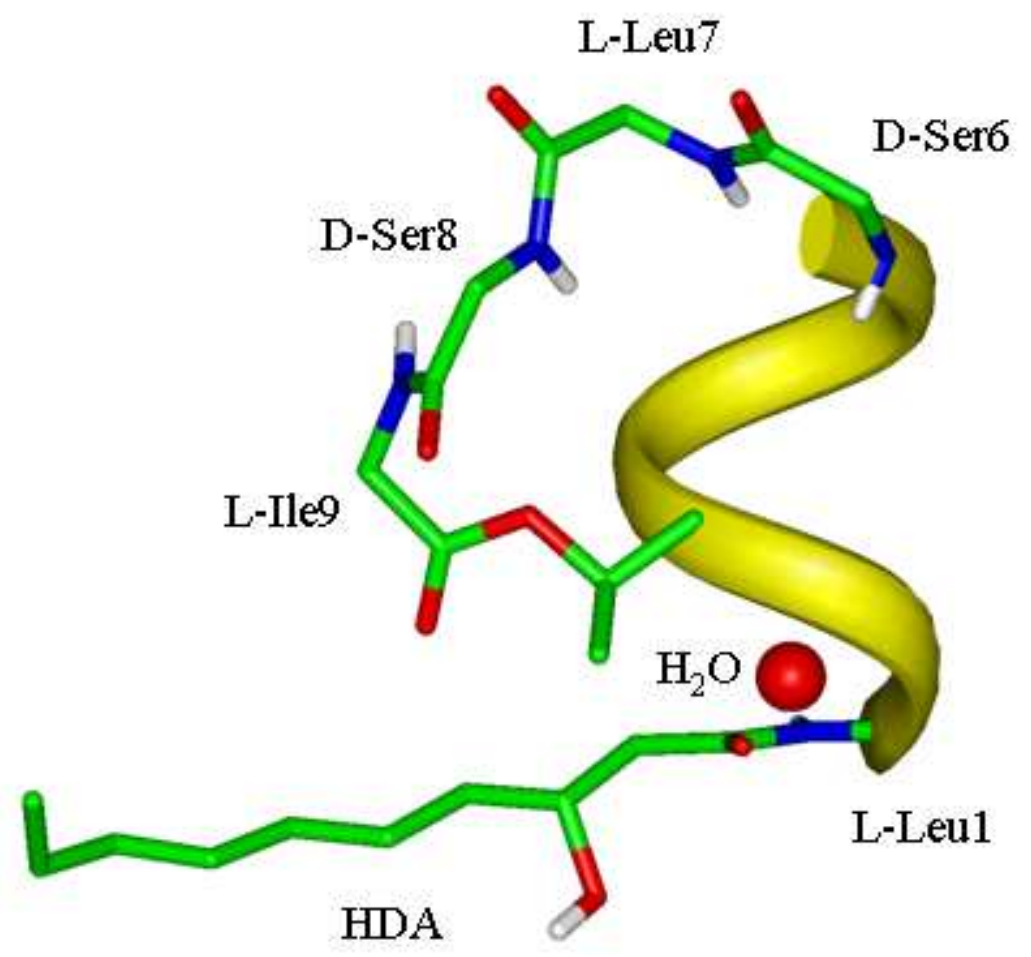




\title{
$\underline{\text { Figure } 4}$
}

\author{
Viscosin group

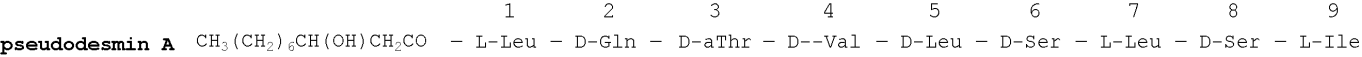 \\ pseudodesmin B $\mathrm{CH}_{3}\left(\mathrm{CH}_{2}\right)_{6} \mathrm{CH}(\mathrm{OH}) \mathrm{CH}_{2} \mathrm{CO}$ - L-Leu - D-Gln - D-aThr - D--Val - D-Leu - D-Ser - L-Leu - D-Ser - L-Val \\ WLIP $\quad \mathrm{CH}_{3}\left(\mathrm{CH}_{2}\right)_{6} \mathrm{CH}(\mathrm{OH}) \mathrm{CH}_{2} \mathrm{CO}$ - L-Leu - D-Glu - D-aThr - D--Val - D-Leu - D-Ser - L-Leu - D-Ser - L-Ile \\ pseudophomin A $\mathrm{CH}_{3}\left(\mathrm{CH}_{2}\right)_{6} \mathrm{CH}(\mathrm{OH}) \mathrm{CH}_{2} \mathrm{CO}$ - L-Leu - D-Glu - D-aThr - D--Ile - D-Leu - D-Ser - L-Leu - D-Ser - L-Ile \\ pseudophomin B $\mathrm{CH}_{3}\left(\mathrm{CH}_{2}\right)_{8} \mathrm{CH}(\mathrm{OH}) \mathrm{CH}_{2} \mathrm{CO}$ - L-Leu - D-Glu - D-aThr - D--Ile - D-Leu - D-Ser - L-Leu - D-Ser - L-Ile \\ viscosin $\quad \mathrm{CH}_{3}\left(\mathrm{CH}_{2}\right)_{6} \mathrm{CH}(\mathrm{OH}) \mathrm{CH}_{2} \mathrm{CO}$ - L-Leu - D-Glu - D-aThr - D--Val - L-Leu - D-Ser - L-Leu - D-Ser - L-Ile \\ viscosinamide $\mathrm{CH}_{3}\left(\mathrm{CH}_{2}\right)_{6} \mathrm{CH}(\mathrm{OH}) \mathrm{CH}_{2} \mathrm{CO}$ - L-Leu - D-Gln - D-aThr - D--Val - L-Leu - D-Ser - L-Leu - D-Ser - L-Ile \\ massetolide A $\mathrm{CH}_{3}\left(\mathrm{CH}_{2}\right)_{6} \mathrm{CH}(\mathrm{OH}) \mathrm{CH}_{2} \mathrm{CO}$ - L-Leu - D-Glu - D-aThr - D-aIle - L-Leu - D-Ser - L-Leu - D-Ser - L-Ile \\ massetolide B $\mathrm{CH}_{3}\left(\mathrm{CH}_{2}\right)_{7} \mathrm{CH}(\mathrm{OH}) \mathrm{CH}_{2} \mathrm{CO}$ - L-Leu - D-Glu - D-aThr - D-aIle - L-Leu - D-Ser - L-Leu - D-Ser - L-Ile \\ massetolide $\mathrm{C} \quad \mathrm{CH}_{3}\left(\mathrm{CH}_{2}\right)_{3} \mathrm{CH}(\mathrm{OH}) \mathrm{CH}_{2} \mathrm{CO}$ - L-Leu - D-Glu - D-aThr - D-aIle - L-Leu - D-Ser - L-Leu - D-Ser - L-Ile \\ massetolide D $\mathrm{CH}_{3}\left(\mathrm{CH}_{2}\right)_{6} \mathrm{CH}(\mathrm{OH}) \mathrm{CH}_{2} \mathrm{CO}$ - L-Leu - D-Glu - D-aThr - D-aIle - L-Leu - D-Ser - L-Leu - D-Ser - L-Leu \\ massetolide $\mathbf{E} \quad \mathrm{CH}_{3}\left(\mathrm{CH}_{2}\right)_{6} \mathrm{CH}(\mathrm{OH}) \mathrm{CH}_{2} \mathrm{CO}$ - L-Leu - D-Glu - D-aThr - D--Val - L-Leu - D-Ser - L-Leu - D-Ser - L-Val \\ massetolide $\mathbf{F} \quad \mathrm{CH}_{3}\left(\mathrm{CH}_{2}\right)_{6} \mathrm{CH}(\mathrm{OH}) \mathrm{CH}_{2} \mathrm{CO}$ - L-Leu - D-Glu - D-aThr - D--Val - L-Leu - D-Ser - L-Leu - D-Ser - L-Leu \\ massetolide $\mathrm{G} \quad \mathrm{CH}_{3}\left(\mathrm{CH}_{2}\right)_{7} \mathrm{CH}(\mathrm{OH}) \mathrm{CH}_{2} \mathrm{CO}$ - L-Leu - D-Glu - D-aThr - D--Val - L-Leu - D-Ser - L-Leu - D-Ser - L-Ile \\ massetolide $\mathbf{H} \quad \mathrm{CH}_{3}\left(\mathrm{CH}_{2}\right)_{2} \mathrm{CH}(\mathrm{OH}) \mathrm{CH}_{2} \mathrm{CO}$ - L-Leu - D-Glu - D-aThr - D--Val - L-Leu - D-Ser - L-Leu - D-Ser - L-Ile
}

\section{Amphisin group}

amphisin $\quad \mathrm{CH}_{3}\left(\mathrm{CH}_{2}\right)_{5} \mathrm{CH}(\mathrm{OH}) \mathrm{CH}_{2} \mathrm{CO}$ - D- eu - D-ASp - D-aThr - D-- eu - D-Teu - D-Ser - L-Teu - D-Gln - tensin $\mathrm{CH}_{3}\left(\mathrm{CH}_{2}\right)_{6} \mathrm{CH}(\mathrm{OH}) \mathrm{CH}_{2} \mathrm{CO}-\mathrm{D}$-Leu - D-Asp - D-aThr - D--Leu - D-Leu - D-Ser - L-Leu - D-Gln - L-Leu - L-Ile - L-Glu 


\section{Figure 5}

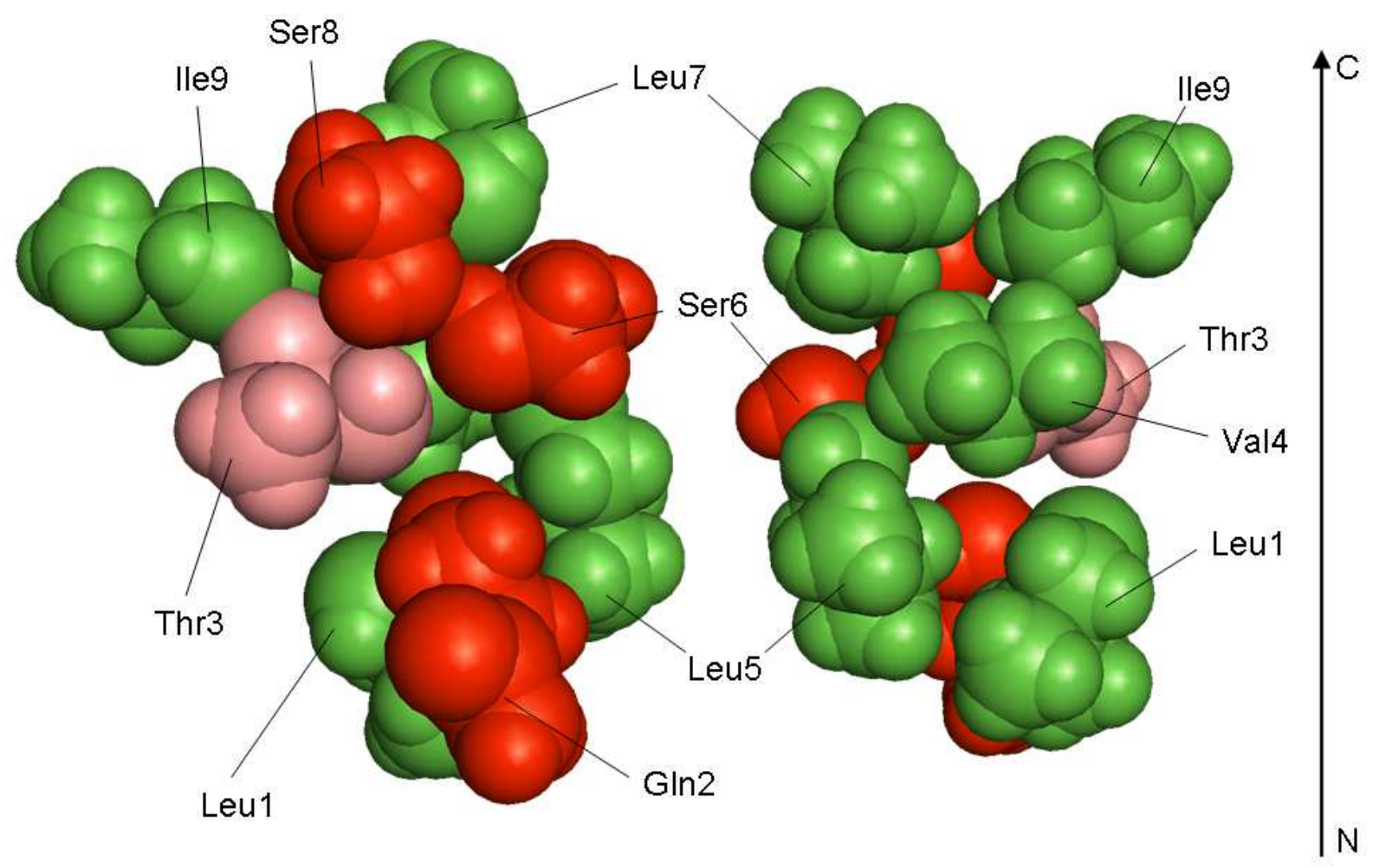




\section{STRUCTURE AND X-RAY CONFORMATION OF PSEUDODESMIN A AND B, TWO NEW CYCLIC LIPODEPSIPEPTIDES FROM PSEUDOMONAS BACTERIA}

Davy Sinnaeve ${ }^{\mathrm{a}, *}$, Catherine Michaux ${ }^{\mathrm{b}}$, Johan Van hemel ${ }^{\mathrm{c}}$, Jan Vandenkerckhove ${ }^{\mathrm{c}}$, Eric Peys ${ }^{\mathrm{c}}$, Frans A.M. Borremans ${ }^{\mathrm{a}}$, Benedikt Sas ${ }^{\mathrm{c},}$, Johan Wouters $^{\mathrm{b}}$ and José C. Martins ${ }^{\mathrm{a}, *}$

${ }^{a}$ NMR and Structure Analysis Unit, Department of Organic Chemistry, Ghent University, Krijgslaan 281 S4 B-9000 Gent, Belgium

${ }^{\mathbf{b}}$ Laboratoire de Chimie Biologique Structurale, Université de Namur, rue de Bruxelles 61, B-5000 Namur, Belgium

${ }^{\mathrm{c} K e m i n}$ Pharma, Atealaan 4H, B-2200 Herentals, Belgium

${ }^{\dagger}$ Current address: Department of Food Safety and Food Quality, Ghent University, Coupure Links 653, blok B, 9000 Gent, Belgium

*Corresponding authors. Tel. +32 (0)9 264 4469; fax: +32 (0)9 2644972

E-mail adresses: Davy.Sinnaeve@UGent.be (D. Sinnaeve), Jose.Martins@UGent.be (J. C. Martins)

\section{$\underline{\text { Supplementary Data }}$}

Contents

Experimental procedures on the culturing, isolation and purification of pseudodesmin A and B in large quantities

1D ${ }^{1} \mathrm{H}, 2 \mathrm{D}{ }^{1} \mathrm{H}-{ }^{15} \mathrm{~N}$ HSQC and ${ }^{1} \mathrm{H}-{ }^{13} \mathrm{C}$ HSQC spectra with assignments

Rapport provided by the Research Institute for Chromatography (RIC, Kortrijk, Belgium): Analysis of pseudodesmin $A$ and $B$ by high resolution mass spectrometry 


\section{Experimental procedures on the culturing, isolation and purification of pseudodesmin $A$ and $B$ in large quantities}

A 100 litre fermentor, equipped with rhuston impellers and baffles to increase the mixing properties of the vessel, was used for the fermentation. The seed culture was inoculated with $0.01 \%$ of a frozen seed stock. One percent of the seed culture was inoculated into the fermentation media prepared with essential salts, $3 \%$ tryptic soy broth and $0.5 \%$ yeast extract. Cultures were incubated for five days at $28^{\circ} \mathrm{C} \pm 1{ }^{\circ} \mathrm{C}$. Agitation was adjusted to maintain a dissolved oxygen concentration of $20 \%$ throughout the duration of the fermentation. The $\mathrm{pH}$ of the culture was not controlled. A defoaming agent was added during the fermentation. After approximately 19 hours of growth, the fermentor was fed with a $50 \%$ cerelose solution at a rate of $1.0-1.75 \mathrm{~g} / \mathrm{l} \cdot \mathrm{h}$ for the duration of the fermentation. The fermentation culture was harvested at 110 hours post inoculation and centrifuged at approximately $10500 \times \mathrm{g}$ for 15 minutes at $25^{\circ} \mathrm{C}$. The centrate was then concentrated up to 20 fold by hollow fiber filtration (HFF) with a 0.2 filter. The retentate was collected and heated to $80^{\circ} \mathrm{C}$ for 15 minutes and then centrifuged again at $13500 \times \mathrm{g}$ for 15 minutes at $25^{\circ} \mathrm{C}$. The centrate was collected, frozen for a minimum of 4 hours at $-80^{\circ} \mathrm{C}$ and freeze-dried for a minimum of 5 days.

The freeze dried material $(160 \mathrm{~g})$ was rewetted with $240 \mathrm{ml}$ water and extracted 4 times with ethyl acetate. The combined ethyl acetate fractions (total volume of 2.5 litre) were dried in vacuo, which gave $2.65 \mathrm{~g}$ of residue. The residue was redissolved in ethyl acetate and a first purification was done using a normal phase open column (Kieselgel 60, 230-400 mesh ASTM, Merck) with following eluents: hexane, hexane/acetone (1/1), acetone, acetone/methanol (9/1), acetone/methanol (1/1) and methanol. Those fractions that contained product with a molecular mass of $1124.2 \mathrm{Da}$ (determined via LC-MS) were combined. After removal of the solvent in vacuo, the residue $(1.07 \mathrm{~g})$ was purified a second time using open column normal phase chromatography on Kieselgel 60, eluting consecutively with acetone and mixtures of acetone/methanol with ratios (98/2), (95/5) and (90/10). Again those fractions that contained product with a molecular mass of 1124.2 Da were combined. In the LC-MS chromatogram of the combined fractions, two major peaks could be observed. After the combined fractions were concentrated in vacuo, the residue $(750 \mathrm{mg}$ ) was submitted to preparative HPLC using a Gilson 322 pump system equipped with a Beckman Ultrasphere RP-18 column (particle size $5 \mu \mathrm{m}$ ) $(150 \times 10 \mathrm{~mm})$ was used in order to separate the major peaks. Detection was done with a Gilson UV/VIS-156 detector set at wavelength of $210 \mathrm{~mm}$. The eluent used was acetonitrile and water with $0.1 \%$ trifluoroacetic acid (TFA) (ratio 60/40; flow $7.5 \mathrm{ml} / \mathrm{min}$ ). The total length of one run was 40 minutes. The peaks eluting at 13 minutes (pseudodesmin B), respectively 23 minutes (pseudodesmin A) were collected and yielded $260 \mathrm{mg}$ and $27 \mathrm{mg}$ of pseudodesmin A and B as white solids respectively, which corresponds to $0.163 \%$ and $0.0169 \%$ of weight compared to the collected freeze dried biological material. 


\section{D ${ }^{1} \mathrm{H}, 2 \mathrm{D}{ }^{1} \mathrm{H}-{ }^{15} \mathrm{~N}$ HSQC and ${ }^{1} \mathrm{H}-{ }^{13} \mathrm{C}$ HSQC spectra with assignments}

The following spectra are provided:

- p.4: $700 \mathrm{MHz} 1 \mathrm{D}{ }^{1} \mathrm{H}$ spectrum of pseudodesmin A in acetonitirle-d3 solution at $298.0 \mathrm{~K}$

- p.5: $700 \mathrm{MHz} 1 \mathrm{D}{ }^{1} \mathrm{H}$ spectrum of pseudodesmin B in acetonitirle-d3 solution at $298.0 \mathrm{~K}$

- $\quad$.6: $700 \mathrm{MHz} 2 \mathrm{D}{ }^{1} \mathrm{H}_{-}{ }^{15} \mathrm{~N}$ HSQC spectrum of pseudodesmin A in acetonitirle-d3 solution at $298.0 \mathrm{~K}$, with assignment of all cross-peaks due to ${ }^{1} \mathrm{~J}_{\mathrm{NH}}$ correlations

- p.7-8: $700 \mathrm{MHz} 2 \mathrm{D}{ }^{1} \mathrm{H}^{-13} \mathrm{C}$ HSQC spectrum of pseudodesmin A in acetonitirle-d3 solution at $298.0 \mathrm{~K}$, with assignment of all cross-peaks due to ${ }^{1} \mathrm{~J}_{\mathrm{CH}}$ correlations

The $700 \mathrm{MHz}$ 1D spectra were recorded with a spectral width of $10.99 \mathrm{ppm}, 32768$ time domain points and an acquisition time of $2.13 \mathrm{~s}$. Before Fourier transform, all spectra were zero filled until 131072 real data points. No window function was applied. A zero order polynomial baseline correction was performed.

All 2D spectra were acquired and processed as described in the main paper. 


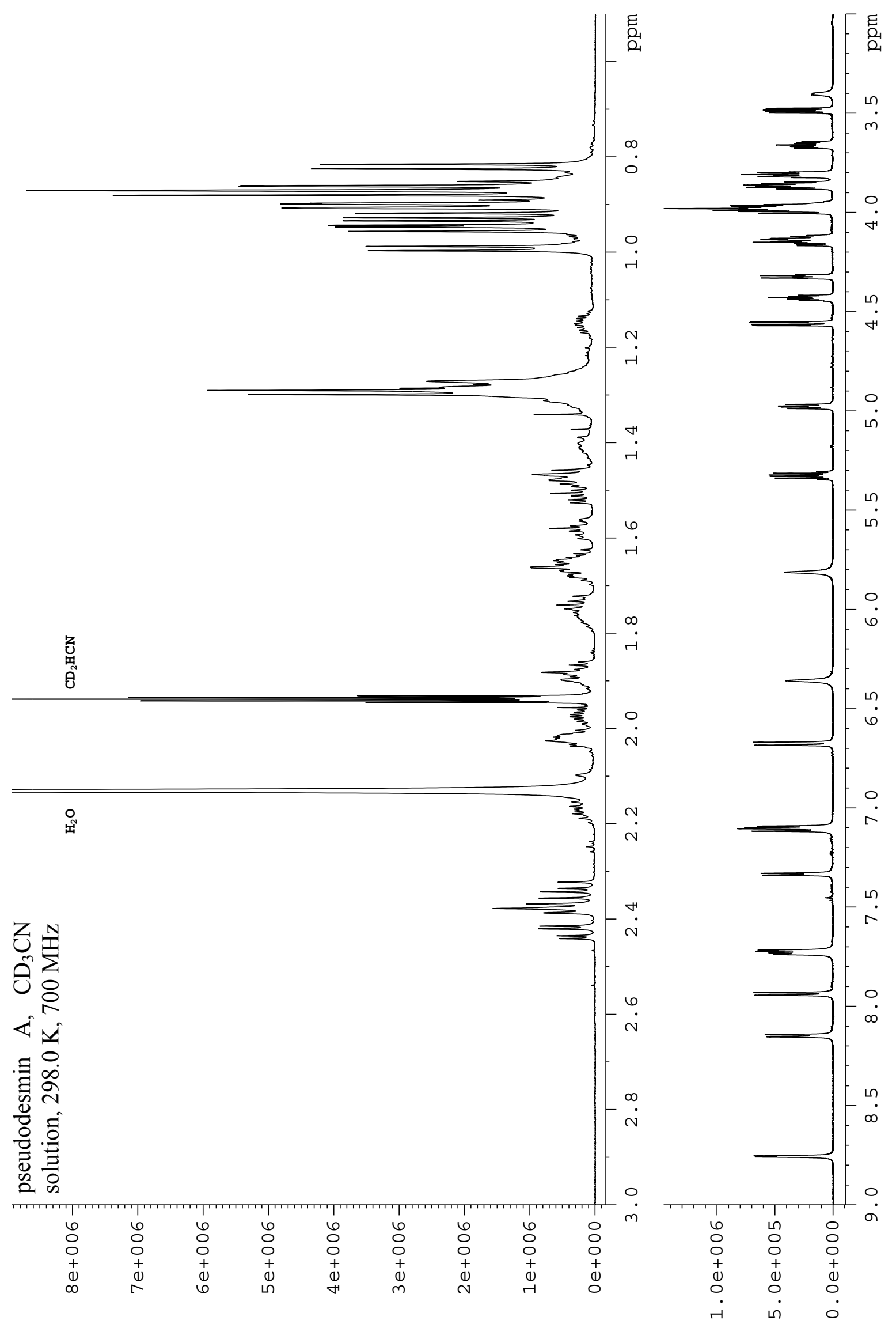









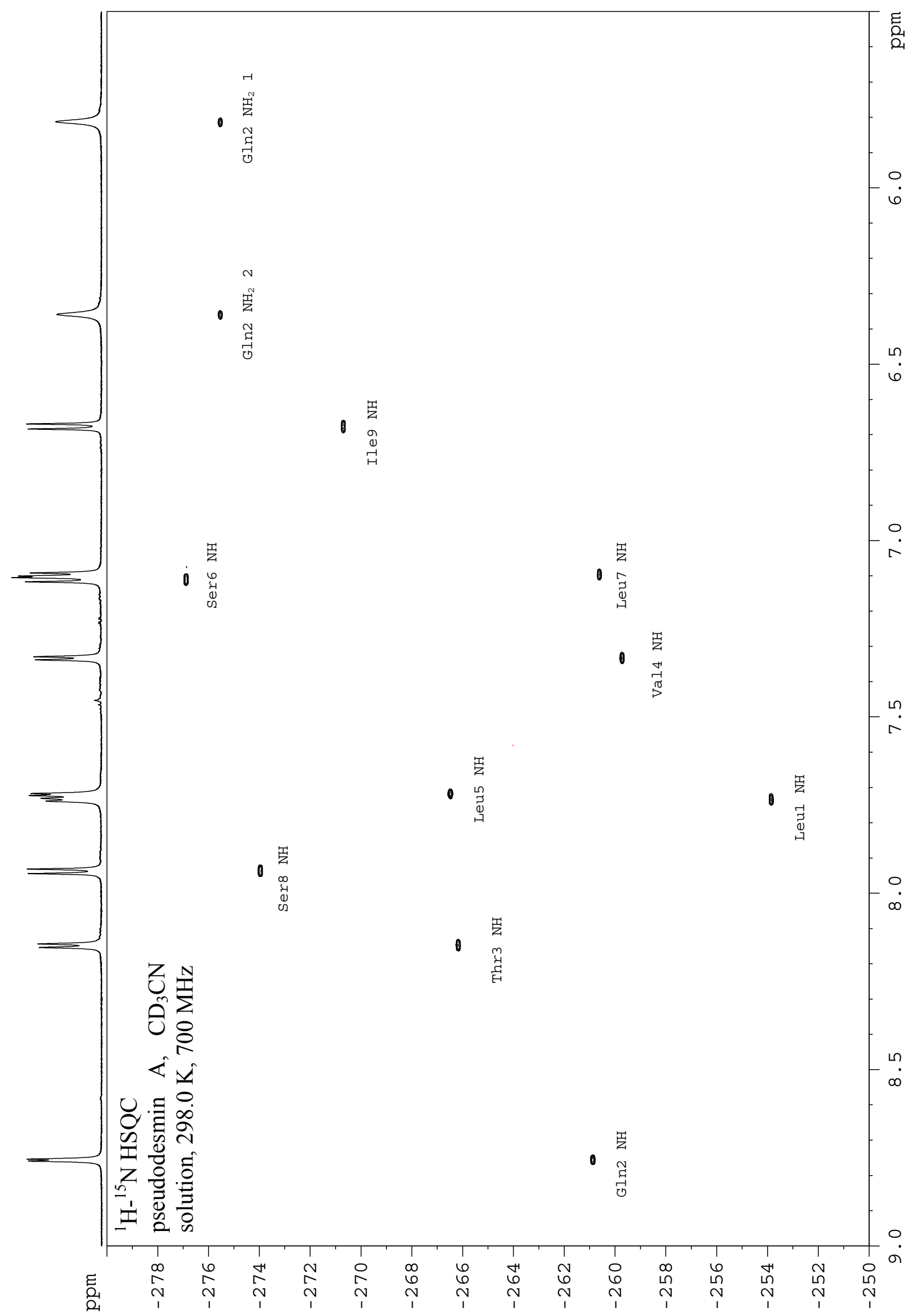




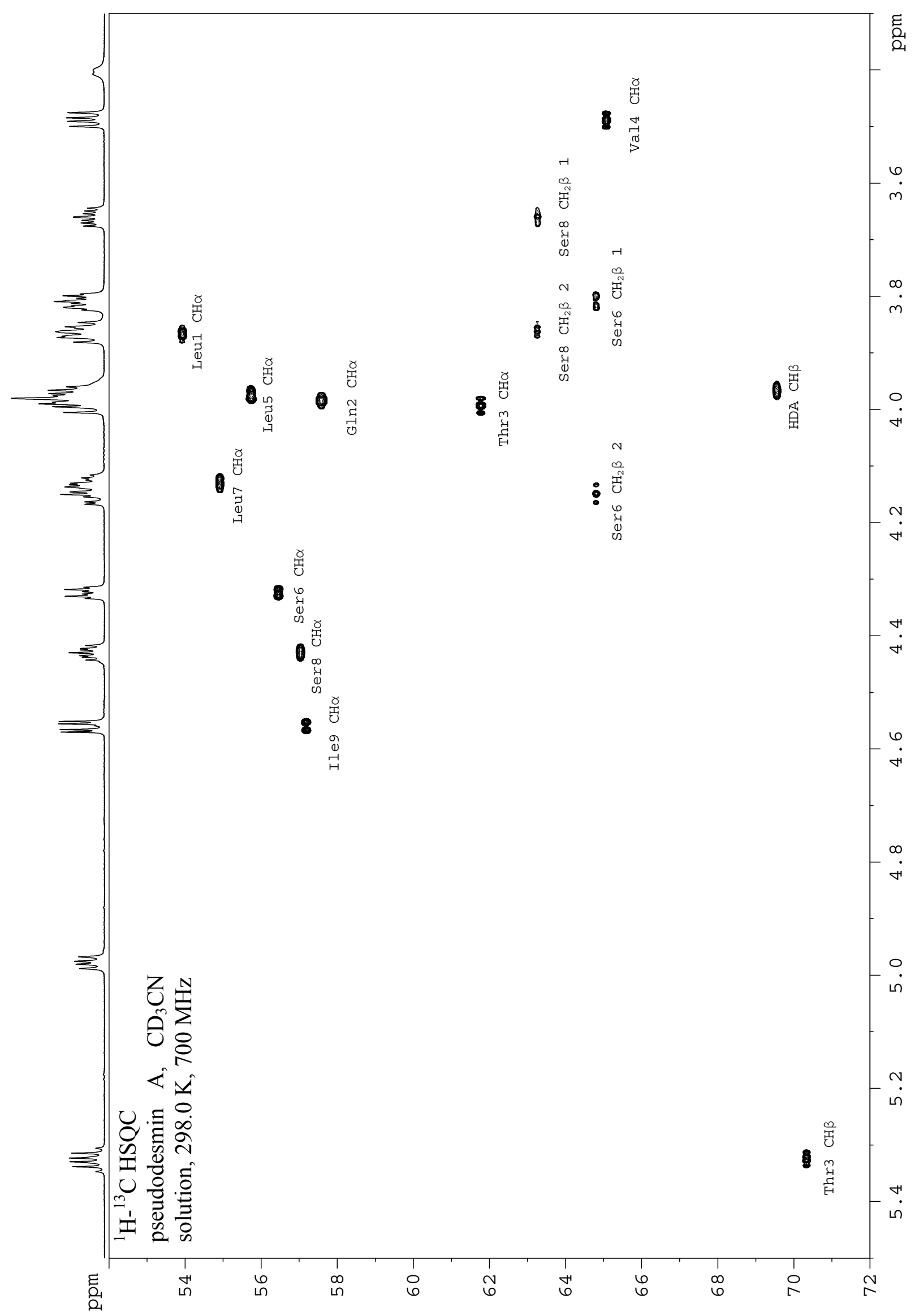




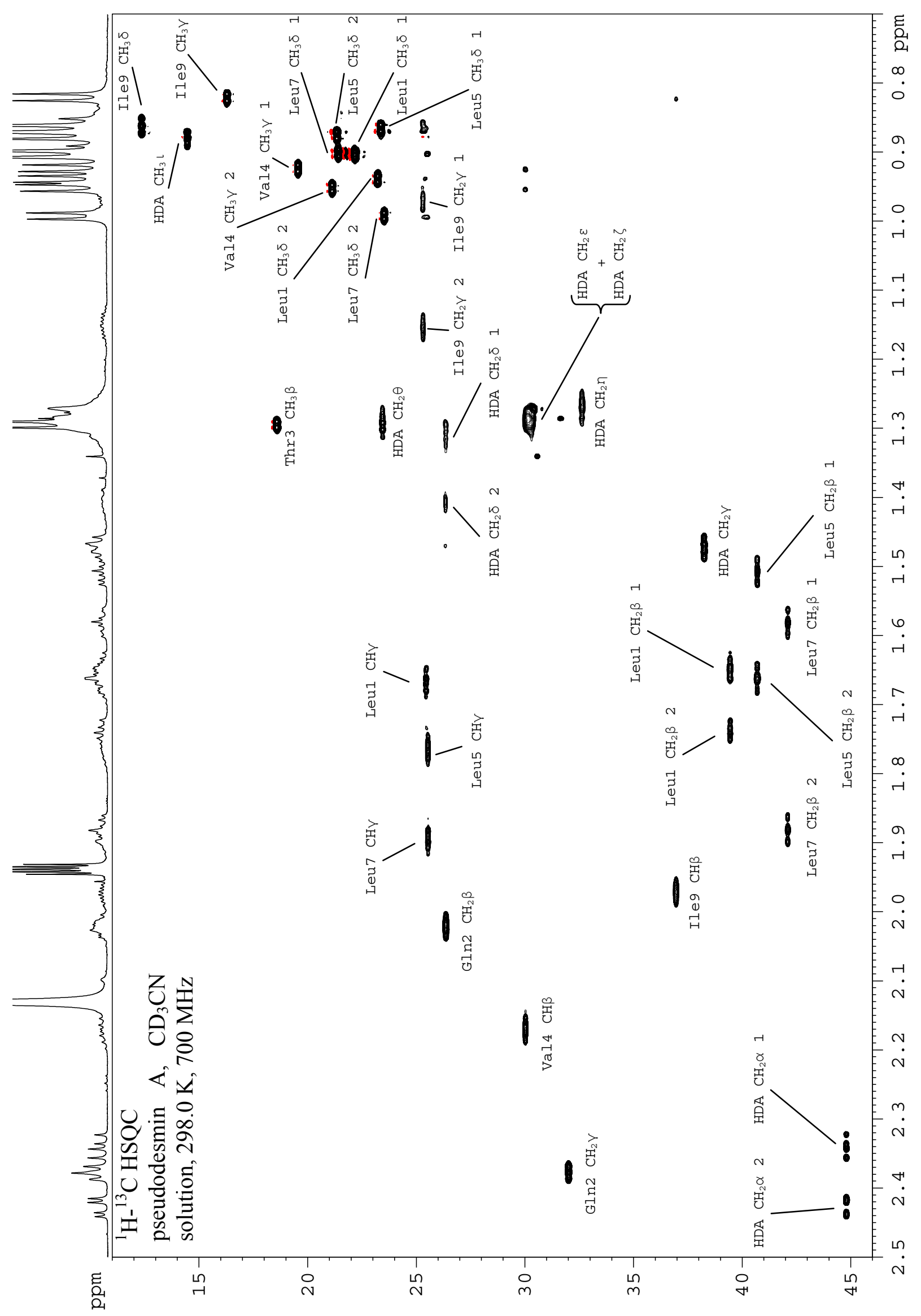




\section{RIC \\ Research Institute \\ for Chromatography}

\section{Analysis of Pseudodesmin A and B by High Resolution Mass Spectrometry}

Written by: Dr. Alberto dos Santos Pereira

Approved by: Dr. Pat Sandra

Kennedypark 26, Kortrijk, B8500, Belgium 


\title{
Experimental
}

\author{
Samples
}

Samples of pseudodesmin A and B were dissolved at $500 \mathrm{ppm}$ in acetonitrile.

\section{Solvents and reagents}

Acetonitrile and water were of LC/MS grade from Biosolve (Valkenswaard, The Netherlands) and formic acid was supplied by Sigma-Aldrich (Steinheim, Germany).

\section{Analytical instrumentation}

\section{HPLC conditions}

An Agilent 1200 LC system (Agilent Technologies, Waldbronn, Germany) was used. The HPLC column was BEH C 18 (Waters, Zellik, Belgium) $100 \mathrm{~mm} \times 2.1 \mathrm{~mm}$ ID x $1.7 \mu \mathrm{m} \mathrm{d}_{\mathrm{p}}$, using the isocratic mobile phase: formic acid $0.05 \%$ /acetonitrile $(20 / 80 ; \mathrm{v} / \mathrm{v})$ with a mobile phase flow of $0.3 \mathrm{~mL} / \mathrm{min}$. The injection volume was $0.5 \mu \mathrm{L}$.

\section{TOF conditions}

Agilent LC/MSD TOF mass spectrometer (Agilent Technologies, Waldbronn, Germany). Instrument control and data acquisition was performed by Mass Hunter software (Agilent Technologies). The analytical conditions are presented in the table 1. 
Table 1. TOF conditions used for the analysis of the pseudodesmin samples.

\begin{tabular}{|c|c|c|c|}
\hline Parameter & Value & Parameter & Value \\
\hline Min Range $(\mathrm{m} / \mathrm{z})$ & 700 & Max Range $(\mathrm{m} / \mathrm{z})$ & 1600 \\
\hline Length transients & 72864 & $\begin{array}{l}\text { Abs. Centroid Threshold } \\
\text { (counts) }\end{array}$ & 500 \\
\hline Fragmentor (V) & 175 & Skimmer (V) & 60 \\
\hline OCT RF V (V) & 250 & Gas Temp $\left(^{\circ}\right)$ & 350 \\
\hline Drying gas (I/min) & 9 & Nebulizer (psig) & 35 \\
\hline Capillary (V) & 3500 & $\begin{array}{l}\text { Reference mass } \\
\text { correction }\end{array}$ & Enable \\
\hline $\begin{array}{l}\text { Minimum Height } \\
\text { (counts) }\end{array}$ & 500 & $\begin{array}{l}\text { Reference mass list } \\
\qquad(\mathrm{m} / \mathrm{z})\end{array}$ & $\begin{array}{r}922.009798 \\
1521.971475 \\
\end{array}$ \\
\hline
\end{tabular}




\section{RESULTS}

The chromatogram of the sample pseudodesmin $A$ is shown in figure 1 and the mass spectrum is shown in figure 2 . The mass spectrum shows ion $[M+H]^{+}$with $\mathrm{m} / \mathrm{z} 1125.71396$. This ion has less than $1 \mathrm{ppm}$ difference of the protonated ion from molecule $\mathrm{C}_{54} \mathrm{H}_{96} \mathrm{~N}_{10} \mathrm{O}_{15}$. The data for this mass formula calculation is shown in table 2 .

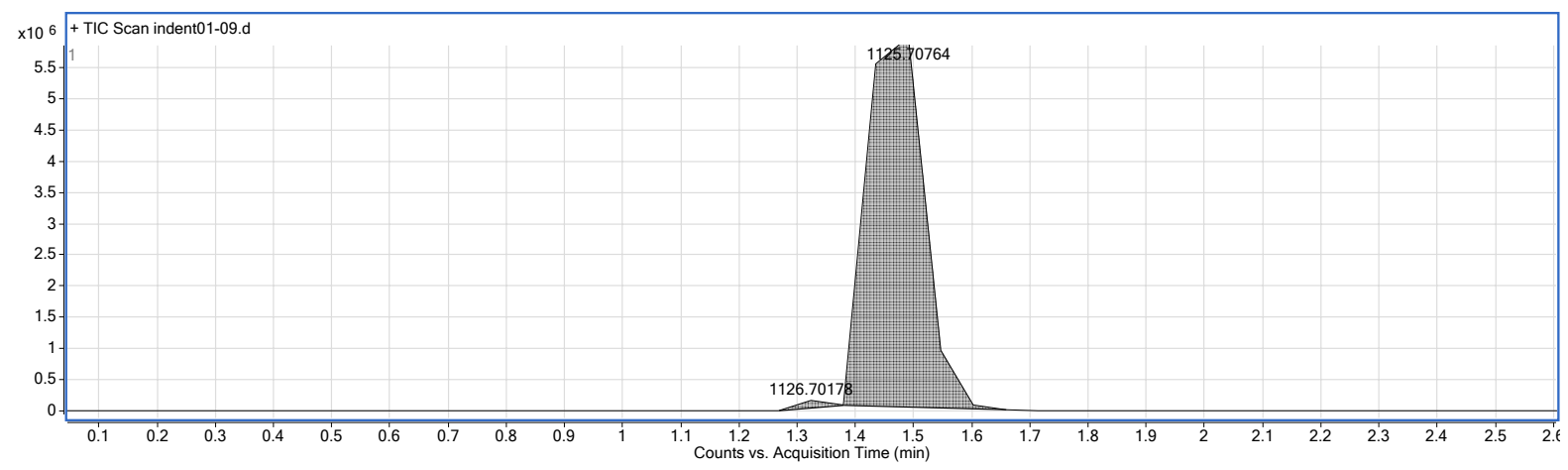

Figure 1. The chromatogram of the pseudodesmin A.

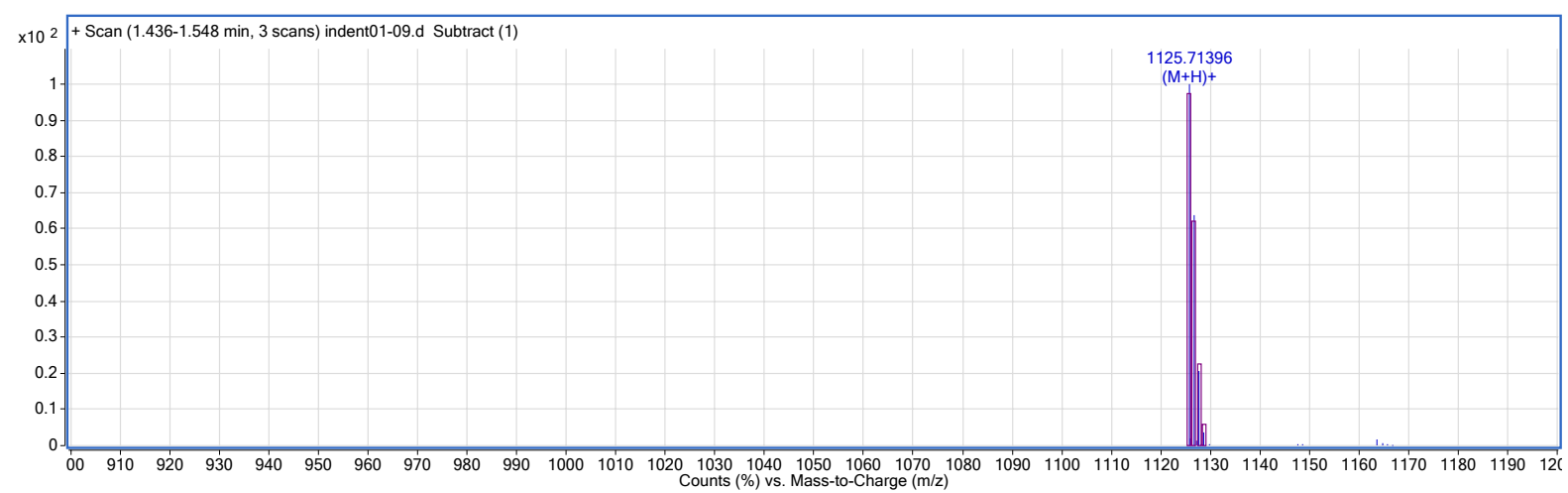

Figure 2. The mass spectra obtained by TOF analysis of the pseudodesmin A. 
Table 2. Results from the molecule formula calculation of the sample pseudodesmin A.

\begin{tabular}{|lllllll|}
\hline Formula $(\mathrm{M})$ & \multicolumn{2}{c}{$\mathrm{C}_{54} \mathrm{H}_{96} \mathrm{~N}_{10} \mathrm{O}_{15}$} & \multicolumn{2}{l}{ lon Formula m/z } & $\mathrm{C}_{54} \mathrm{H}_{97} \mathrm{~N}_{10} \mathrm{O}_{15}$ \\
\hline Isotope & $\mathrm{m} / \mathrm{z}$ & Calc $\mathrm{m} / \mathrm{z}$ & Abund. \% & $\begin{array}{l}\text { Calc. Abund. } \\
(\%)\end{array}$ & $\begin{array}{l}\text { Difference } \\
\text { (ppm) }\end{array}$ & $\begin{array}{l}\text { Difference } \\
(\mathrm{mDa})\end{array}$ \\
\hline $\mathbf{1}$ & 1125.71396 & 1125.71294 & 100 & 100 & -0.91 & -1.02 \\
\hline $\mathbf{2}$ & 1126.71685 & 1126.71599 & 63.76 & 63.75 & -0.76 & -0.86 \\
\hline $\mathbf{3}$ & 1127.71964 & 1127.71879 & 20.54 & 23.08 & -0.76 & -0.85 \\
\hline $\mathbf{4}$ & 1128.72234 & 1128.72148 & 3.44 & 6.08 & -0.76 & -0.86 \\
\hline
\end{tabular}

The chromatogram of the sample pseudodesmin $B$ is shown in figure 3 and the mass spectrum in figure 4 . The mass spectra shows basically the ion $[M+H]^{+}$with $\mathrm{m} / \mathrm{z} 1111.70019$. This ion has $2.61 \mathrm{ppm}$ difference of the protonated ion from the molecule with formula $\mathrm{C}_{53} \mathrm{H}_{94} \mathrm{~N}_{10} \mathrm{O}_{15}$. The complete data for this mass formula calculation is shown in table 3.

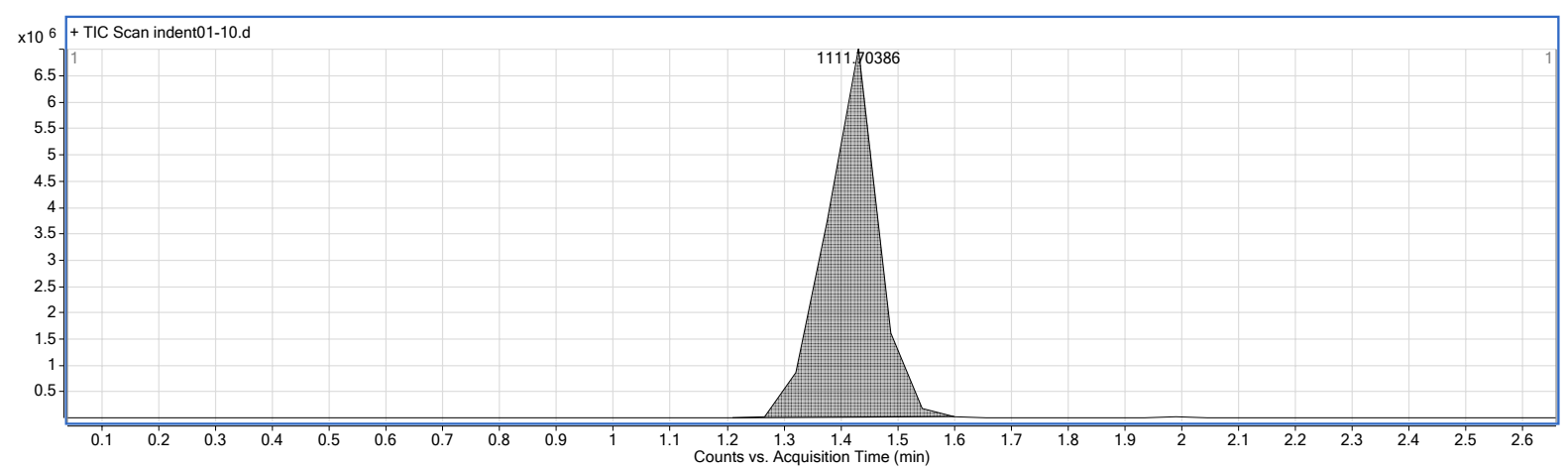

Figure 3. The chromatogram of the pseudodesmin B. 


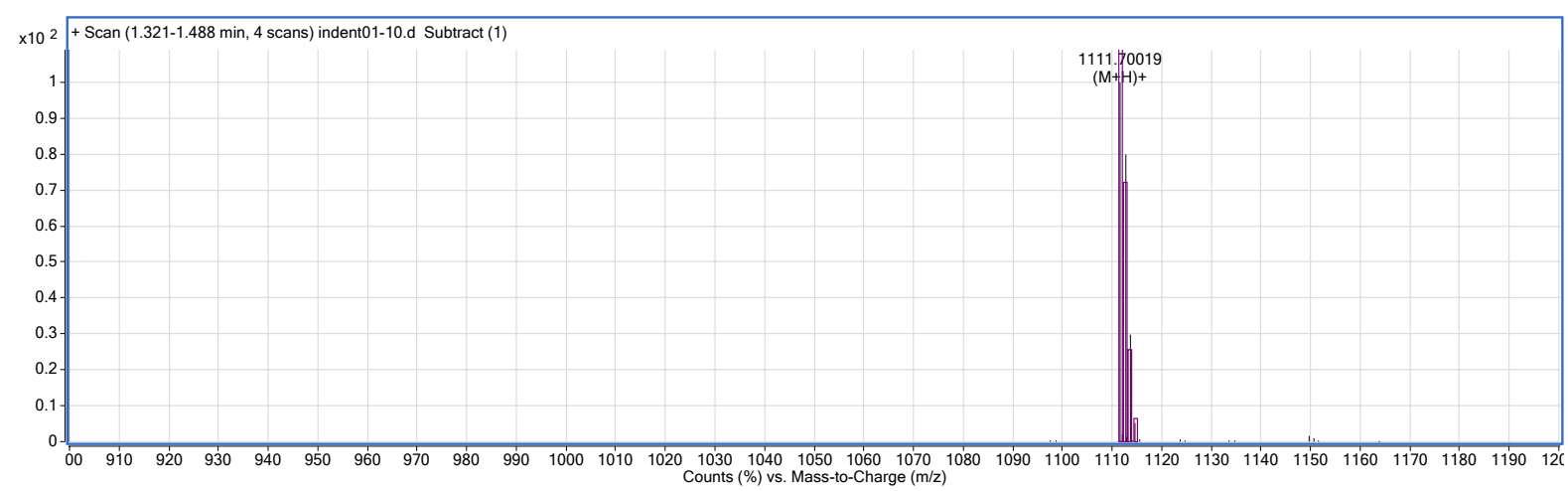

Figure 4. The mass spectra obtained by TOF analysis of the pseudodesmin B.

Table 3. Results from the molecule formula calculation of the sample pseudodesmin B.

\begin{tabular}{|c|c|c|c|c|c|c|}
\hline \multicolumn{2}{|c|}{ Formula (M) } & \multicolumn{2}{|c|}{$\mathrm{C}_{53} \mathrm{H}_{94} \mathrm{~N}_{10} \mathrm{O}_{15}$} & Ion Formula $\mathrm{m} / \mathrm{z}$ & \multicolumn{2}{|c|}{$\mathrm{C}_{53} \mathrm{H}_{95} \mathrm{~N}_{10} \mathrm{O}_{15}$} \\
\hline Isotope & $\mathrm{m} / \mathrm{z}$ & Calc $\mathrm{m} / \mathrm{z}$ & Abund. \% & $\begin{array}{l}\text { Calc. Abund. } \\
\text { (\%) }\end{array}$ & $\begin{array}{l}\text { Difference } \\
\text { (ppm) }\end{array}$ & $\begin{array}{l}\text { Difference } \\
(\mathrm{mDa})\end{array}$ \\
\hline 1 & 1111.70019 & 1111.69729 & 100 & 100 & -2.61 & -2.90 \\
\hline 2 & 1112.69878 & 1112.70033 & 79.99 & 62.64 & 1.40 & 1.55 \\
\hline 3 & 1113.69989 & 1113.70312 & 29.61 & 22.38 & 2.90 & 3.23 \\
\hline 4 & 1114.70367 & 1114.70580 & 5.22 & 5.83 & 1.91 & 2.13 \\
\hline
\end{tabular}

\section{Conclusion}

Based on the TOFMS analyses the molecular formulas $\mathrm{C}_{54} \mathrm{H}_{96} \mathrm{~N}_{10} \mathrm{O}_{15}$ for pseudodesmin $A$ and $\mathrm{C}_{53} \mathrm{H}_{94} \mathrm{~N}_{10} \mathrm{O}_{15}$ for pseudodesmin $\mathrm{B}$ were attributed. 